\title{
Weather Forecast Based Rice Advisory Services in Bangladesh
}

N M F Rahman ${ }^{*}$, M C Rahman², M A Baten ${ }^{3}$, M I Hossain¹, S M Q Hassan4, R Ahmed ${ }^{1}$, M M Hossain5, ABM Z Hossain6, M A Aziz¹, M M

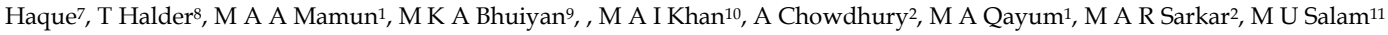
and M S Kabir 12

\begin{abstract}
Strengthening the early warning system to forecast extreme weather and provide action-oriented advisories may increase rice yield as well as enhance the income of the farmers through minimizing risks and losses, if proper use of the generated advisory is ensured. This study assessed the importance and impact of weather forecast based advisory service (WFBAS) in Bangladesh. Literature review and field experimental data were used in a sensitivity analysis to show the impact of WFBAS on rice production. Available literatures suggested that the weather based advisory service would enhance rice yield by around $6.7-10 \%$, but the experimental findings revealed that yield advantage could be $21.48 \%$. Besides, the adoption of this technology would reduce the cost of cultivation by $12 \%$, whereas the aggregate impact would increase the farmers' profit by $25 \%$. In the sensitivity study, we considered the production and price of Aman and Boro seasons (actual and government procured prices for 2018-19) and assumed only $6.70 \%$ yield increase with $5 \%$ farmers adopting of WFBAS. As such, additional 0.172 million tons will be added to the national rough rice production and thus the nation will be benefited by 3143 million Bangladeshi taka (BDT) at the actual farmgate price and it would be 4478 million BDT at the government procured price. The return on one BDT investment in this technology would be 51-73 BDT based on actual and procured prices. The projection showed enhenced production of the rough rice at 0.119 million tons and 0.214 million tons by 2025 and 2030, on which the additional return would be BDT 2441 and BDT 5223 million at the projected actual farmgate price and BDT 3522 and BDT 6979 million at the projected Government procured price, respectively. Hence, the successful implementation of the WFBAS will help to develop resilient rice farming communities, minimize livelihood risk, reduce the cost of production, utilize resources efficienty, and enable the farmers to take maximum benefit from favorable weather conditions through improved agricultural extension services. Finally, the enhanced yield and loss reduction will help to achieve the target of Sustainable Development Goal (SDG) by 2030 through sustaining rice production in Bangladesh under changing climate.
\end{abstract}

Key words: Climate-resilience, farmers' income, future prospects, model verification, sensitivity analysis, sustainable production

\section{INTRODUCTION}

Ensuring food security is a major challenge of a country with an increasing population and reducing agricultural land as well as regular short- and long-term climate hazards (FAO, 2017a). Climate change is predicted to decrease the agricultural share of Bangladesh's Gross Domestic Product (GDP) by 3.1 percent per year (WB, 2011). Rice plays a key role in the cereal crop sector in Bangladesh by generating $90 \%$ of overall food grain production (Agriculture Diary, 2018; Rahman et al., 2020; Siddique et al., 2020). About cent percent population of the country consume rice as their main food at 367 gm person $^{-1}$ day $^{-1}$ (HIES, 2016). It also has a significant $(26 \%$ of total production) non-human consumption (e.g., livestock, fisheries, industries). Therefore, adequate production of rice is one of the keys

\footnotetext{
${ }^{1}$ Agricultural Statistics Division, Bangladesh Rice Research Institute (BRRI), Gazipur-1701, Bangladesh;2Agricultural Economics Division, BRRI, Gazipur-1701, Bangladesh; 3 Professor, Department of Statistics, Shahjalal University of Science and Technology, Sylhet, Bangladesh; ${ }^{4}$ Meteorologist, Storm Warning Centre, Bangladesh Meteorological Department, Dhaka, Bangladesh;'5Entomology Division, BRRI, Gazipur-1701, Bangladesh;' Irrigation and Water Management Division, BRRI, Gazipur-1701, Bangladesh;'Soil Science Division, BRRI, Gazipur-1701, Bangladesh;Plant Physiology Division, BRRI, Gazipur-1701, Bangladesh; ${ }^{9}$ Agronomy Division, BRRI, Gazipur-1701, Bangladesh;10Plant Pathology Division, BRRI, Gazipur-1701, Bangladesh; ${ }^{11}$ Freelance International Consultant (Agricultural Systems), Bangladesh; ${ }^{12}$ Director General, BRRI,Gazipur-1701, Bangladesh.

*Corresponding author's E-mail: niaz.sust@gmail.com (N M F Rahman)
} 
to achieving food security. In fact, 'Rice Security' in Bangladesh is synonymous with 'Food Security', as the most other rice growing countries of the globe (Brolley, 2015).

The national agricultural policy of Bangladesh emphasizes strengthening the early warning system to forecast extreme weather events and provide action-oriented advisories to the farmers as a part of climate-resilient agricultural practices. On the other hand, we aim to enhance the integration of agricultural development and climate resilience by means of climate-smart agriculture. For this, a multipronged approach is required to address the full-scale climate variability and tackle the challenges arising from increasingly frequent weather and climate extremes. There is also high demand among the farming communities for such solutions (Belle, 2019). Increased climatic volatility is a huge constraint on the ability of farmers to make operational and strategic agricultural management decisions that can drastically obstruct rice production. To make the vision possible farmers need to reduce the risks from extreme weather events and address residual risks from climate variability. A recent example is the flash flood in 2017, which caused substantial damage to the production of Boro rice in the north-eastern region of the country, leading to shock in the market and rice imports (2,259 million tons) became the highest in a decade (FAO, $2017 b)$. The weather forecast-based advisory service (WFBAS) has the potentiality to contribute to food security in Bangladesh by generating advisories and awareness of climate change. Whereas, WFBAS is the potential for reducing poverty by enhancing the rice yield and income of the farmers through reducing insect and disease outbreaks, ensuring optimum water use for irrigation, labor, and energy utilization, reduce losses and risks, reduce environmental pollution with thoughtful use of agricultural chemicals through proper management in time and also guides for the selection of the best-suited rice varieties according to the predicted climatic circumstances. This is how the system reduces the overall costs of production and increases the income of the farmers. The adoption of this technology by the agricultural extension services would contribute to achieving the sustainable development goals through enhancing productivity and return of the smallscale food producers.

\section{Weather and its importance in rice management}

The weather has an impact on rice plant's growth and development in all phases. Its volatility during the crop season, such as delay in monsoon onset, heavy rainfall, floods, droughts, severe temperatures may affect crop growth and production and eventually affect product quality and quantity (Hollinger and Angel, 2009). On the other hand, expected climate change combined with other drivers of change is likely to induce the current challenges of agricultural management (Mechiche-Alami and Abdi, 2020). For improving the food security of the country, there lies a residual risk of climate variability. Smaller-scale farmers are less capable of improving productivity under near-normal conditions; they are relatively unable to manage extreme weather incidents. In the absence of knowledge on changing climate (plant-soil-environment relationship), the farmers are highly dependent on the traditional farming understanding, which reduces farm productivity and increases farming problems such as soil salinity, over use of water, fertilizers, pesticides, etc (Nelson et al., 2019).

\section{Weather-based advisory service and traditional management system}

Weather forecasts for agriculture provide the necessary meteorological information to direct the farmers in making real-time special decisions for farm operations. The effects of anomalies of a weather element on a given crop are both at the cropping stage and 
location-specific (Das et al., 2010). So, WFBAS refers to manage the crop by generating growth stage-wise and location-specific agro advisory services based on weather forecasts. While in traditional management practice, the crop is being managed without meteorological information as well as crop-weather interaction.

Generally, agro advisories are issued in respect of weather-induced stresses, field operations, sowing/planting time, application of agricultural inputs, evaporation losses for irrigation, water management, weeding, harvest, and post-harvest operations, the prevalence of pests and diseases considering the crop-weather interaction (Frisvold and Murugesan, 2013) by a group of farm management specialists (agricultural statistician, agricultural meteorologist, plant pathologists, entomologists, agronomists, plant physiologists, soil scientists, and irrigation expert).

\section{Rice advisory services based on the weather forecast}

There are multiple and diverse sources of weather and climate-related threats in agriculture: insufficient water resources, drought, desertification, land loss, erosion, hailstorm, flooding, and much more (Rathore and Chattopadhyay, 2016). Efficient weather and climate information and advisory services will assist farmers in making decisions to strengthen management practices regarding agricultural climate risks (Nesheim et al., 2017). The Agromet/Agro Advisory Services (AAS) therefore plays an immense role in achieving sustainable agricultural productivity in Bangladesh.These services serve farmers' realtime needs and lead to weather forecast-based smart farming strategies and applications to increase crop production and food security. They can make a huge difference in agricultural production by providing benefits to the farmers from benevolent weather and reduce the adverse effects of malevolent weather.

\section{An innovative approach to a specific development challenge}

Several pieces of evidence link unmitigated climatic inconsistency to poor economic progress in emerging countries. Decreasing agricultural resources (e.g. land, labor, soil health, and water), and increasing climate vulnerability (e.g., drought, salinity, flood, heat, and cold wave) appears as the great challenges to keep the pace of food production in the background of increasing population in Bangladesh (Kabir et al., 2015; Kabir et al., 2020). Despite the documented impacts of extreme climate events and increasing concern for future agriculture, climate risk mitigation in many agricultural development strategies appears unaddressed. This may be because the agricultural system has increasingly treated climate as part of the environmental context but never as a resource for management options. The proposed approach promotes considering and managing the full spectrum of risks from weather extremes or climate variability. This novel approach can help rice growers in a better and more coordinated way in response to weather extremes or climate variability that exceeds their inherent coping capacity. This can significantly reduce the disaster risk of the rice farming communities, which is a major development challenge in Bangladesh.

WFBAS is an innovative solution for weather-ready climate-smart techniques for sustainable rice production in Bangladesh. This will enable farmers/decision-makers to make effective decisions on rice crop supervision for different climate conditions, well ahead of time. It will not only reduce the risk but also enable farmers to maximize the benefit from favorable weather conditions. Uptake of the system by the agricultural extension services can contribute to the overall food security of the country and achieve SDGs by enhancing the agricultural productivity and income of the food producers. Therefore, this study has been designed to (i) assess the weather forecast based rice advisory 
system for increasing productivity and show its importance on rice production; (ii) develop and mapping the research, development, and extension (RDE) activities for three decades on disseminating the WFBAS in the rice farming in Bangladesh.

\section{METHODOLOGY}

\section{Weather research and forecasting (WRF) model for medium-range weather forecast}

The Weather Research and Forecasting (WRF) Model is an atmospheric model designed for both research and numerical weather prediction (Power et al., 2017). It is being used for weather forecasts on micro-levels. For the development of the WRF model, a partnership was formed among the National Center for Atmospheric Research (NCAR), the National Oceanic and Atmospheric Administration (NOAA), the U.S. Air Force, the Naval Research Laboratory, the University of Oklahoma, and the Federal Aviation Administration. This model is a numerical weather prediction method of nextgeneration mesoscale designed to serve both the needs of atmospheric science and operational forecasting. This model allows scientists to make real-time predictions of the atmosphere based on real data (observations, analyses). By developing a broader research community, the WRF model performs operational prediction in a flexible and computationally efficient way with the advancement in physics, numeric, and data assimilation.

\section{WRF model validation}

The WRF model predictions were validated with the observed data collected from the Plant Physiology Division of BRRI. The seven days lead time approach was followed in the forecast validation. The plot, normalized rootmean-square error (NRMSE), and relative bias (relBias) were estimated for the verificationofprediction performance.The parameter $\hat{E}_{i}-E_{i}$ represents the error between the predicted and observed values for the $i^{\text {th }}$ sample.
The normalized root means squared error (NRMSE) is the root mean squared error (RMSE) divided by the mean of the observed data. The level of prediction accuracy was assessed by using RMSE, a good predictor that reflects the consistency of the model and its ability to explain the actual behavior of the system.

The NRMSE is provided in Equation 1, where $E_{i}$ is the observed value, $\hat{E}_{i}$ is the model prediction, and $n$ is the total number of predictions.

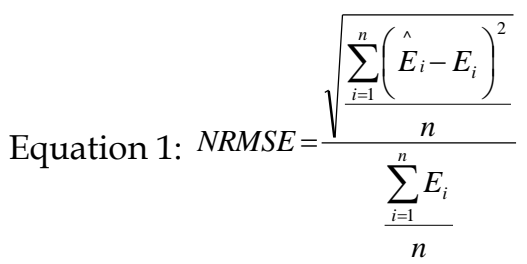

The relative bias (relBias) is the mean of the error in the predictions divided by the mean of the observed data. It indicates whether the model over estimates or under estimates the predictions.

The equation for relBias is provided in Equation 2, where $E_{i}$ is the observed value, $\hat{E}_{i}$ is the model prediction, and $n$ is the total number of predictions in the prediction horizon.

Equation 2: relBias $=\frac{\frac{\sum_{i=1}^{n}\left(\hat{E}_{i}-E_{i}\right)}{n}}{\frac{\sum_{i=1}^{n} E_{i}}{n}}$

\section{Advisory generation}

An expert group comprising of the scientists from Agricultural Statistics, Agricultural Economics, Entomology, Plant Pathology, Plant Physiology, Irrigation \& Water Management, Soil Science, and Agronomy divisions of the Bangladesh Rice Research Institute (BRRI), responsible for conducting research, analyzing weather sensitivity of rice crop at different growth stages and preparing 
advisories (e.g. sowing, weeding, time of pesticides spray, irrigation scheduling, fertilizer application, etc. and overall crop management) based on weather forecasts.

\section{Focus group discussion (FGD)}

FGD's were conducted at three districts of Rajshahi and six districts of Khulna division with respective Deputy Directors (DD), Upazilla Agricultural Officers (UAO), Agricultural Extension Officers (AEO), and Sub Assistant Agriculture Officers (SAAO) of Department of Agricultural Extension (DAE) to draw the dissemination system of appropriate and demand-driven weather forecast based rice management for the farmers.

Experimental materials and methods for evaluation of weather forecast based advisory services

An experiment was conducted by the agromet lab of BRRI in Aus seasons at the locations listed in Fig. 1. The locations represent the West, Northwest, South, and central part of Bangladesh.

The Randomized Control Block (RCB) design has been used as a field experimental design with three replications. The experiment was aimed to assess the effectiveness of WFBAS regarding yield enhancement of rice varieties.

The WRF model was used from May to August 2016 for localized daily weather forecasting of minimum and maximum temperature, rainfall, and relative humidity. After that, the weather forecast based advisory bulletin was prepared once a week for a specific location. The weather forecast was done 7 days ahead to generate advisories for crop management and pest protection. That advisories were followed into the WFBAS experimental plots at four locations and other plots were managed through usual practices. The advisory bulletins were sent directly to the scientific assistant of the respective locations every Sunday/Monday during the study period. Data were collected through regular field visits and as per the datasheet. Observed weather data and the monthly normal value of different weather parameters were collected from Bangladesh Meteorological Department. BRRI dhan 48 was tested under two different treatments (Treatment $1, \mathrm{~T}_{1}=$ usual practice i.e., control, and Treatment 2, $\mathrm{T}_{2}=$ weather-based advisory service). Each experimental plot was comprised of $5 \mathrm{~m} \times 2 \mathrm{~m}$. A full dose of $\mathrm{P}, \mathrm{K}$, and $\mathrm{S}$ was applied at final land preparation on both $\mathrm{T}_{1}$ and $\mathrm{T}_{2}$. At maturity, a $5.0 \mathrm{~m}^{2}$ area was harvested for grain yield with an adjustment of $14 \%$ moisture content. All other agronomic and pest management practices were also followed according to usual practice in $\mathrm{T}_{1}$. However, sowing, transplanting, weeding, irrigation, fertilizer, herbicides, and pesticide application were adjusted based on the information generated from the weather forecast in the $\mathrm{T}_{2}$ (Table 1 ).

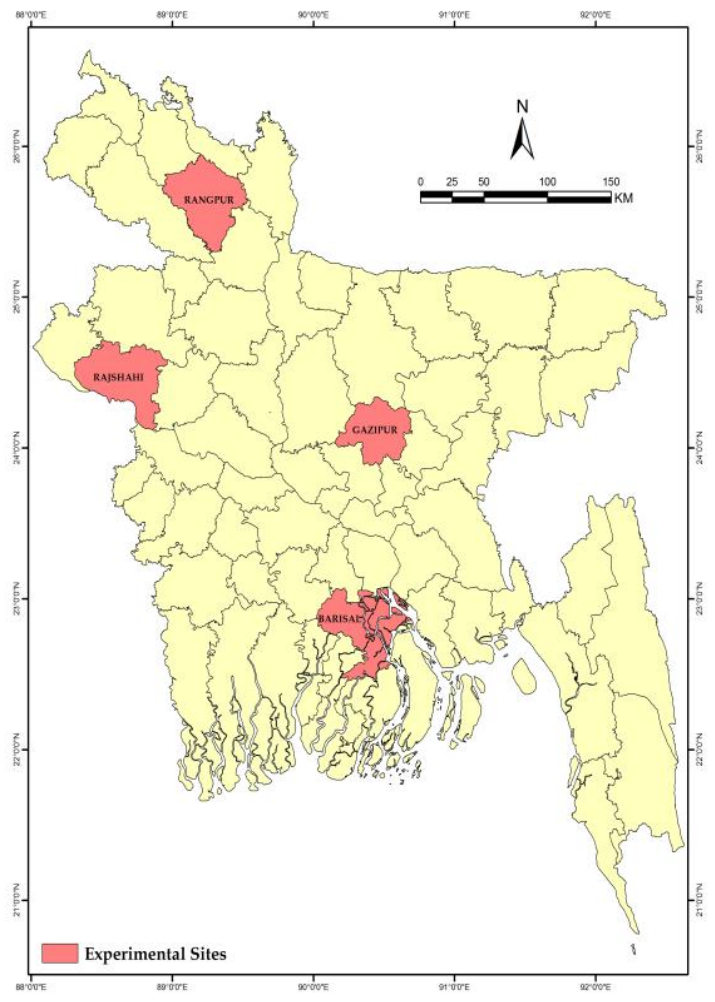

Fig. 1. Experimental locations.

Rice Advisory Services 
Table 1. Field application of management practices.

\begin{tabular}{l|l|l}
\hline Management & $\mathrm{T}_{1}$ : Control & $\mathrm{T}_{2}:$ WFBAS \\
\hline Land preparation & Usual practice & Same as $\mathrm{T}_{1}$ \\
\hline Transplanting & Usual practice & Same as $\mathrm{T}_{1}$ \\
\hline Herbicide application & Applied 1 time & Did not use \\
\hline Weeding & Weeded 3 times & $\begin{array}{l}\text { Delayed and weeded } \\
\text { 2 times }\end{array}$ \\
\hline Fertilizer application & Applied 3 top-dress of Urea & Delayed and applied 3 top-dress of Urea \\
\hline Fungicide application & Applied 2 times & Did not use \\
\hline Insecticide application & Applied 3 times & $\begin{array}{l}\text { Delayed and applied } \\
\text { 2 times }\end{array}$ \\
\hline Irrigation & Irrigated 9 times & Irrigated 6 times \\
\hline Harvesting & Usual practice & Same date as $\mathrm{T}_{1}$ \\
\hline
\end{tabular}

Note: Control= usual practice; WFBAS= Weather forecast based advisory service

The supplementary irrigation was used in the $\mathrm{T}_{1}$ plot whenever necessary, while in the case of $\mathrm{T}_{2}$ we waited for the rainfall according to the forecast and maintained alternate wetting and drying (AWD) system. The date of the different doses of urea fertilizer $12 \mathrm{~kg}$ per bigha was applied based on the forecasted information on rainfall, temperature, sunshine, humidity, and the adjusted irrigation time. We did not adjust the regular planting time of the Aus season in our experiment. However, it also can be adjusted based on the forecasted rainfall information for a week. Combined analyses of variance were performed for four locations to estimate the mean yield, mean square error, and coefficient of variation.

\section{Impact assessment through sensitivity analysis}

In order to assess the impact of WFBAS with a sensitivity analysis, the study employed data from various sources. The rice production (34.44 million tons) data have been collected from the weekly crop report of DAE and converted to rough rice by considering standard conversion protocol $(1 \mathrm{~kg}$ rough rice $=0.67 \mathrm{~kg}$ clean rice). Agricultural household (16.5 million) information has been generated from $\mathrm{DAE}$, and rough rice procurement price for Aman and Boro (26 BDT per kg) has been taken from FPMU, 2019. The actual price of rough rice (18.25 BDT per $\mathrm{kg}$ ) paid to the farmers has been taken from the annual review report of BRRI, 2019. The one-minute voice SMS and text SMS charges are 0.50 BDT for each by the telecom company of Bangladesh, has been considered for estimating the cost of disseminating the generated advisories. The mathematical calculation was used to evaluate the system. Besides, the return on investment (ROI) in this technology has been estimated using the following formula:

$R O I=\frac{\text { Net return on investment }}{\text { Cost of investment }} \times 100 \%$

Here, the net return is the additional benefit from rice production by employing the WFBAS, and the cost of adopting this technology by the farmers is the voice SMS and text SMS charges by the telecom company of Bangladesh. It is important to mention that the required system to establish this technology is already existing in the DAE setup (e.g., FIAC). The web-based decision support system for the automatic weather forecast, advisory generation, and dissemination has been developed by the agro-meteorology and crop modeling laboratory of BRRI. Therefore, no additional fixed cost is required for disseminating this technology to the farmers.

\section{Future prospect assessment of WFBAS}

In order to show the importance of the WFBAS, we have projected the rice production, actual farmgate, and government procurement rough rice prices of Aman and 
Boro seasons up to 2030. For this, we have employed Autoregressive Integrated Moving Average (ARIMA) and compound exponential growth model. The data used in the models are historical farmgate rough price from BRRI and Government procured price from Foodgrain Procurement and Monitoring Unit (FPMU), Ministry of Food. Historical rice production data has been collected from various published issues of the Bangladesh Bureau of Statistics (BBS).

\section{RESULTS AND DISCUSSION}

\section{Experimental evaluation of weather-based advisory services}

The spatial and temporal variations in significant weather parameters (e.g., temperature, humidity, rainfall, wind speed, etc.) have a major influence on farming options such as variety selection, input use, crop management, crop protection measures, harvesting, and threshing. The lack of timely and reliable weather information is a serious constraint to efficient farm planning operations. However, it may not be possible to completely avoid all farm losses due to weather parameters, but it can be minimized to some degree by implementing changes through timely and accurate weather forecast information.

\section{Observed and projected weather condition during experimentation}

In the assessment, the observed maximum and minimum temperature $\left({ }^{\circ} \mathrm{C}\right)$, relative humidity $(\%)$, and rainfall ( $\mathrm{mm})$ in experimental locations was compared with the respective predicted values generated from the WRF model. It should note that the generated output by the WRF model is on weekly basis.

The comparison of observed maximum temperatures for the season (May to August 2016) with the predicted maximum temperatures from the WRF model for the experimental locations indicated that the observed seasonal average maximum temperature was $33.18^{\circ} \mathrm{C}$, with a maximum of $39.50^{\circ} \mathrm{C}$ at Rajshahi, and a minimum of $25.40^{\circ} \mathrm{C}$ at Barishal means maximum temperature varied between 25.40 and $39.50^{\circ} \mathrm{C}$ during May. The predicted results show that the average maximum temperature was $33.37^{\circ} \mathrm{C}$ with a range between $25^{\circ} \mathrm{C}$ and $41.5^{\circ} \mathrm{C}$, which was slightly higher than the observed. A maximum of $41.15^{\circ} \mathrm{C}$ was predicted for Rajshahi in May and a minimum of $25^{\circ} \mathrm{C}$ for Rangpur in August. The variation (standard error of the mean) during the season was 0.10 for both the case of observed and predicted maximum temperature. According to the average maximum temperature of a monthly basis, the temperature was higher in the month of June into the entire season for both observed and predicted cases, which were 33.74 and $34.44^{\circ} \mathrm{C}$, respectively, and according to the location, Rajshahi was the hottest area where average observed maximum temperature was $34.40^{\circ} \mathrm{C}$ and average predicted maximum temperature was $34.64^{\circ} \mathrm{C}$ (Fig. 2a). So, in the case of observed and predicted temperature, we found June as the month and Rajshahi as the location for the highest maximum temperature.

The observed seasonal average minimum temperature was $25.76^{\circ} \mathrm{C}$, with a maximum of $28.80^{\circ} \mathrm{C}$ at Barishal and Gazipur, and a minimum of $18.50^{\circ} \mathrm{C}$ at Rangpur, while the predicted average minimum temperature was $27.09^{\circ} \mathrm{C}$, with a range of $23.06-30.75^{\circ} \mathrm{C}$ during May. Both, maximum and minimum of $30.75^{\circ} \mathrm{C}$ and $23.06^{\circ} \mathrm{C}$ were predicted for Rajshahi and Rangpur, respectively in the month of May. So, the predicted minimum temperature was found higher than the observed. The standard error of the mean during the season was calculated at 0.08 and 0.06 for the case of observed and predicted maximum temperature, respectively. According to the average minimum temperature on a monthly basis, in August and June, the highest minimum temperature was found into the entire season for observed and predicted cases with 26.63 and $27.54^{\circ} \mathrm{C}$, respectively (Fig. 2b). In Barishal and Rajshahi, 
the predicted temperature was higher than the observed temperature. The highest observed average minimum temperature was $26.16^{\circ} \mathrm{C}$
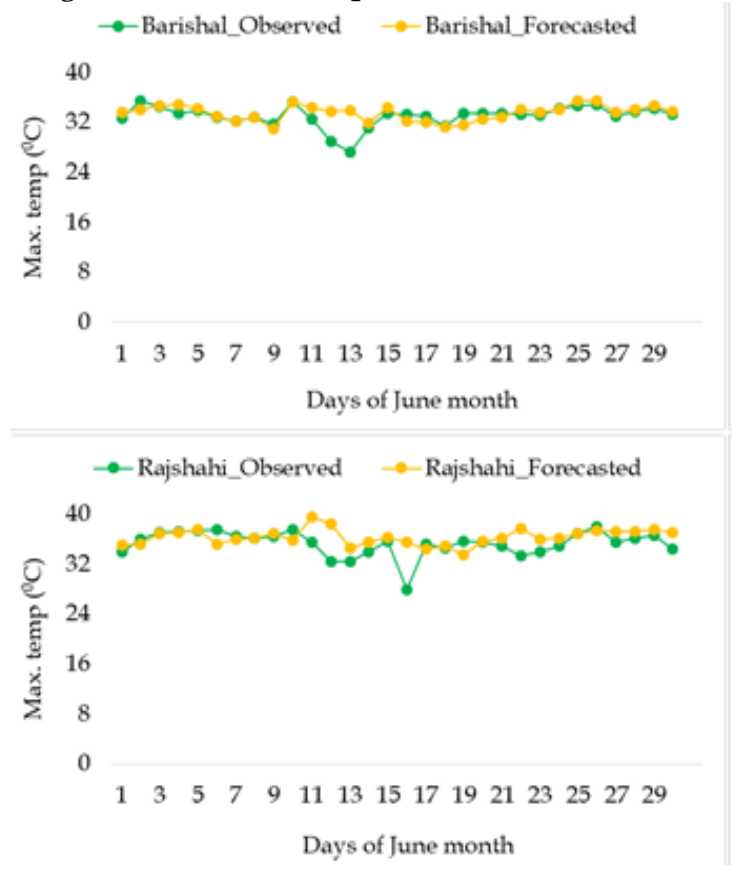

and the highest predicted average minimum temperature was $27.75^{\circ} \mathrm{C}$.

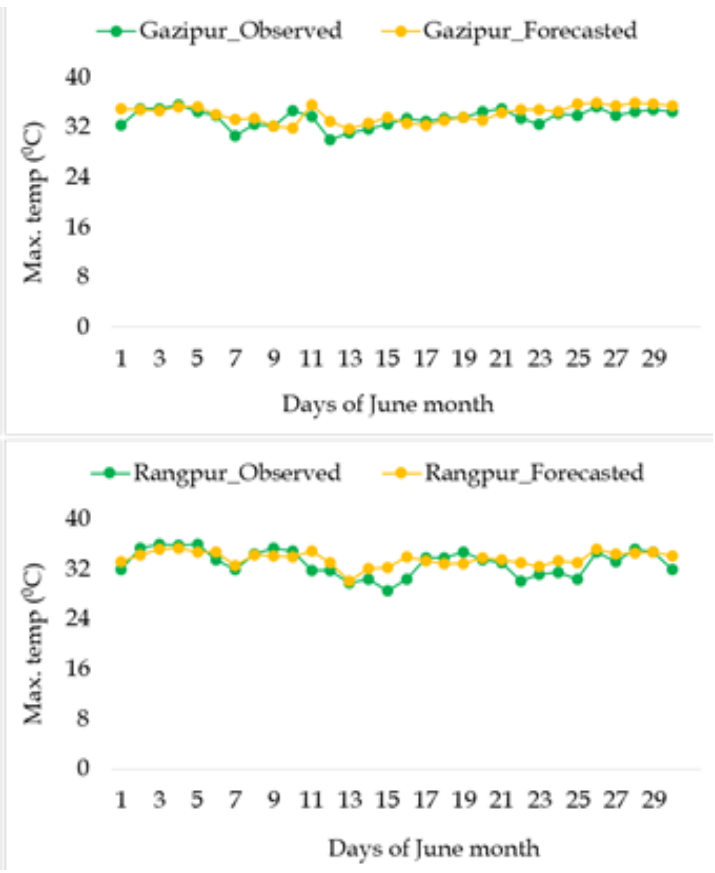

Fig. 2a. Daily observed and predicted maximum temperature $\left({ }^{\circ} \mathrm{C}\right)$ for June 2016 at experimental locations.

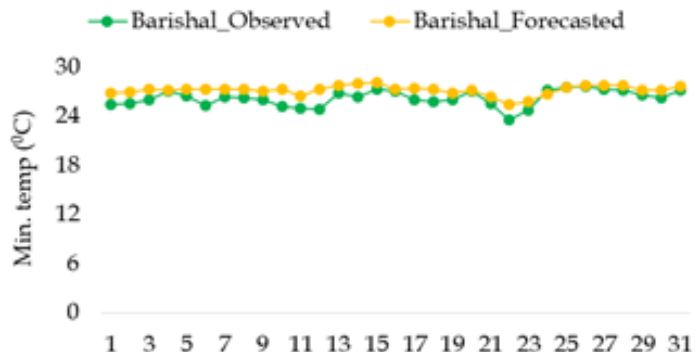

Days of August month

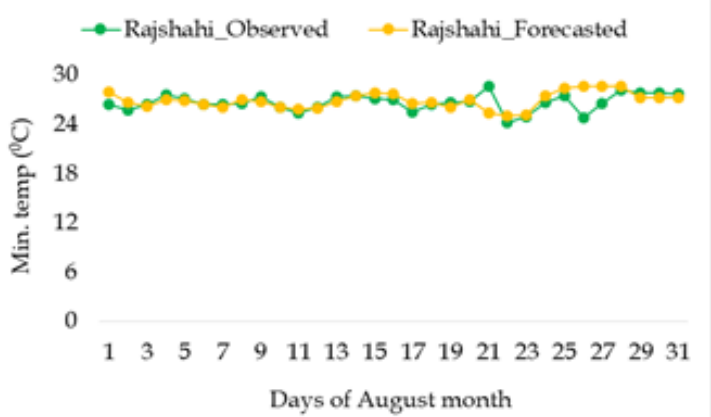

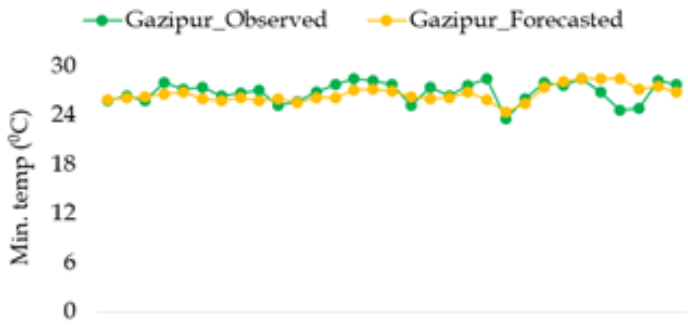

$\begin{array}{llllllllllllllll}1 & 3 & 5 & 7 & 9 & 11 & 13 & 15 & 17 & 19 & 21 & 23 & 25 & 27 & 29 & 31\end{array}$ Days of August month

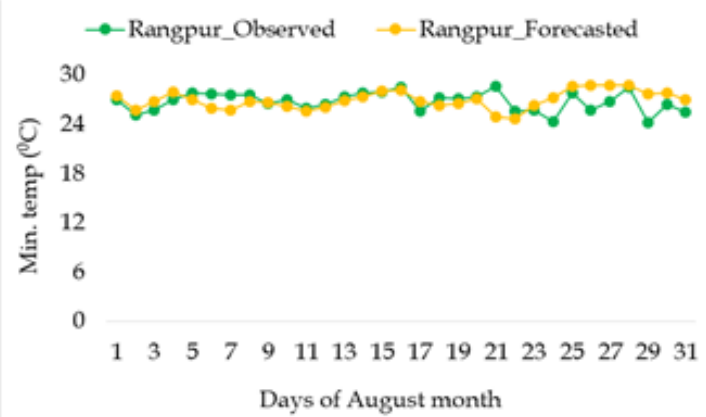

Fig. 2b. Daily observed and predicted minimum temperature $\left({ }^{\circ} \mathrm{C}\right)$ for August 2016 at experimental locations. 
The observed seasonal average relative humidity was $82.89 \%$, with a maximum of $100 \%$ during July-August at Gazipur, Rangpur, and Rajshahi, and a minimum of $56 \%$ during June at Rajshahi, which indicates a range of $56-100 \%$ containing a standard error of the mean 0.34 . In the case of prediction, the average relative humidity was $77.74 \%$, with a range of $43.55-100 \%$. A maximum of $100 \%$ was projected for Rajshahi in August and a minimum of $43.55 \%$ for Rajshahi in May with a standard error of the mean as 0.42 . So, the predicted relative humidity was found lower than the observed. According to the average relative humidity on a monthly basis, July was the high-humid month into the entire season for observed with $86.63 \%$, and for prediction, it was August with $82.75 \%$ (Fig. 2c). Barishal was the high-humid area as its average relative humidity was $86.98 \%$ for observed and $81.45 \%$ for predicted.
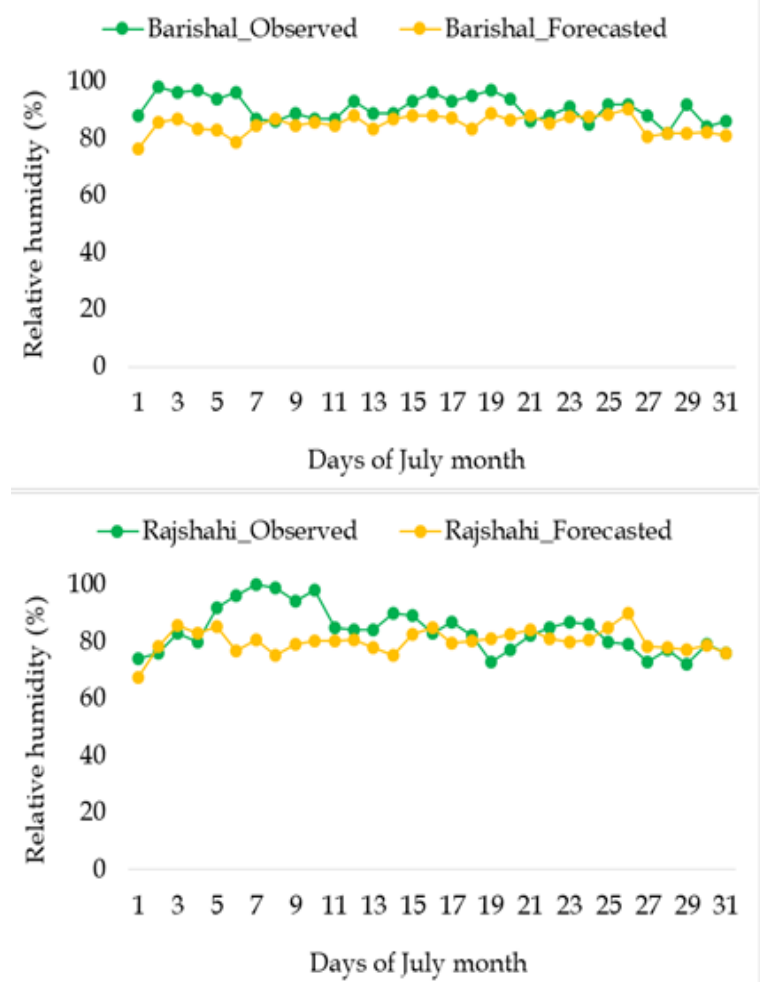

Among all the locations, the observed average seasonal rainfall was $1323.48 \mathrm{~mm}$, with a maximum total amount of rainfall was $2009 \mathrm{~mm}$ in July, and a minimum of $956 \mathrm{~mm}$ in June, while the predicted average seasonal rainfall was $1523 \mathrm{~mm}$, with a maximum of $2191 \mathrm{~mm}$ in July, and a minimum of $1002 \mathrm{~mm}$ in June (Fig. 2d). In other ways, the number of total rainy days for observed and predicted rainfall during the season was 266 and 389, respectively. So, the predicted rainfall and rainy days both were higher than the observed. The average observed and predicted rainfall over the location and month was 10.76 and $12.38 \mathrm{~mm}$ per day with a standard error of the mean 0.98 and 0.71 , respectively. If we consider the location, rainfall was highest in Barishal, and in Rajshahi, it was the lowest. The total rainfall for Barishal and Rajshahi during the season was 1827 and $865 \mathrm{~mm}$ for observed and 1638 and $1247 \mathrm{~mm}$ for predicted.

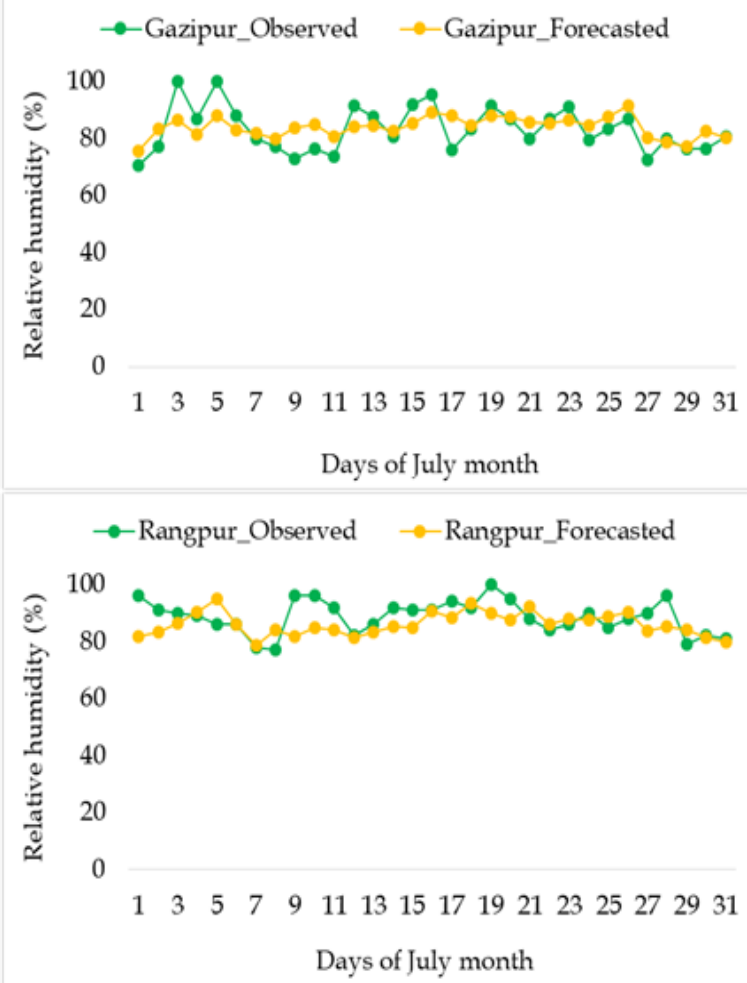

Fig. 2c. Daily observed and predicted relative humidity (\%) for July 2016 at experimental locations. 

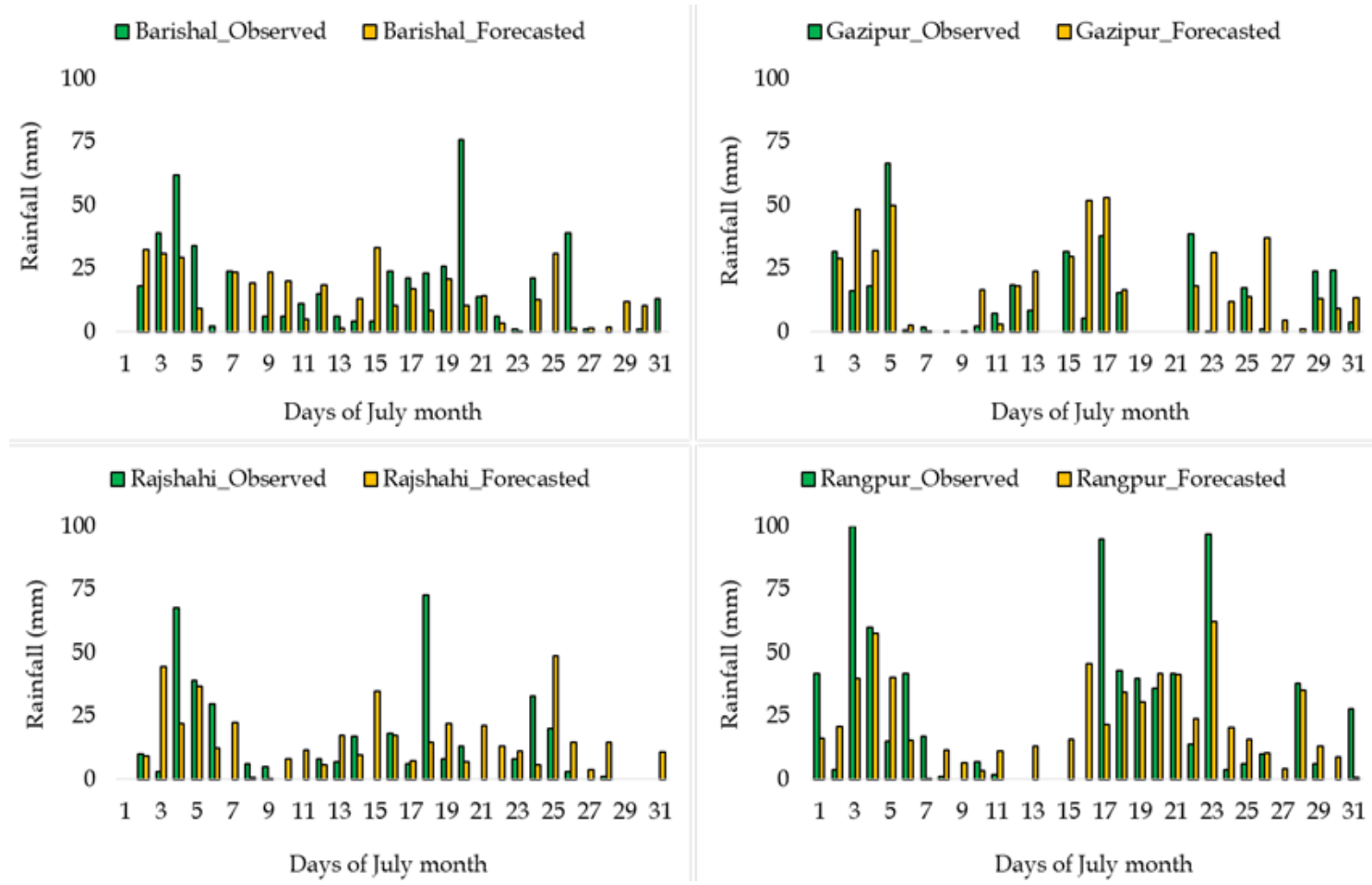

Fig. 2d. Daily observed and projected rainfall (mm) for July 2016 at experimental locations.

\section{Observed and normal weather condition during experimentation}

The average maximum temperature was higher than the normal throughout the season for all months and locations except May month at Rangpur. The average monthly observed maximum temperature was compared with normal, which varied between 0.77 and $1.34^{\circ} \mathrm{C}$ for Barishal, 0.51, and $1.98^{\circ} \mathrm{C}$ for Gazipur, 0.22 , and $1.95^{\circ} \mathrm{C}$ for Rajshahi, and 0.64 to $2.04^{\circ} \mathrm{C}$ for Rangpur(Fig. $3 a)$. The observed average minimum temperature showed a higher value compared to the normal for Barishal (varied from 0.60 to $1.02^{\circ} \mathrm{C}$ ), Rajshahi (0.36 to $0.59^{\circ} \mathrm{C}$ ), and Rangpur $\left(0.53\right.$ to $\left.0.88^{\circ} \mathrm{C}\right)$ but the different scenario was found during the month of May at Rajshahi $\left(0.27^{\circ} \mathrm{C}\right)$ and Rangpur $\left(1.20^{\circ} \mathrm{C}\right)$. In the case of Gazipur, the difference was very minimum varied from -
0.18 to $0.52^{\circ} \mathrm{C}$ (Fig. 3b). The average relative humidity depicts almost the same as the normal throughout the season for Barishal (varied from 0.23 to $0.65 \%$ ), the only exception is the month of May $(-3.55 \%)$. The observed average relative humidity was found lower than normal for Gazipur and its ranges from 0.27 to $7.07 \%$. Other than May (1.52\%), Rajshahi depicts the lower observed average relative humidity than normal ranges from 2.19 to $3.70 \%$. The situation is inverse for Rangpur compared to Rajshahi. Except for May $(0.77 \%)$,other months revealed higher observed value than normal, which varied from 1.13 to $3.03 \%$ (Fig. 3c). For rainfall, May and July exceeded the normal amount of rainfall but June and August revealed less rainfall compared to normal for all the locations except during August in Barishal (Fig. 3d). 


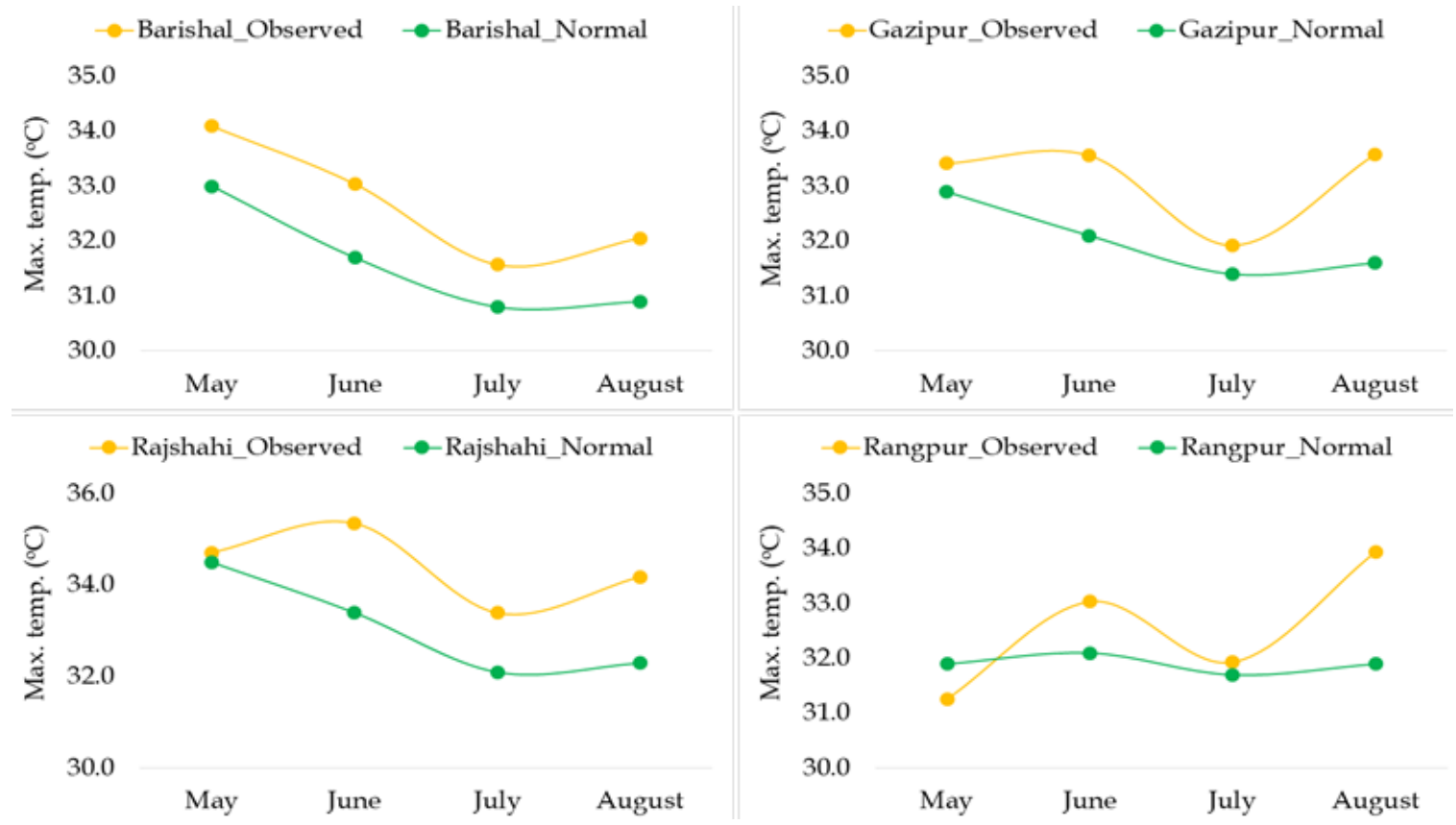

Fig. 3a. Monthly observed and normal average maximum temperature $\left({ }^{\circ} \mathrm{C}\right)$ for the experimental locations.

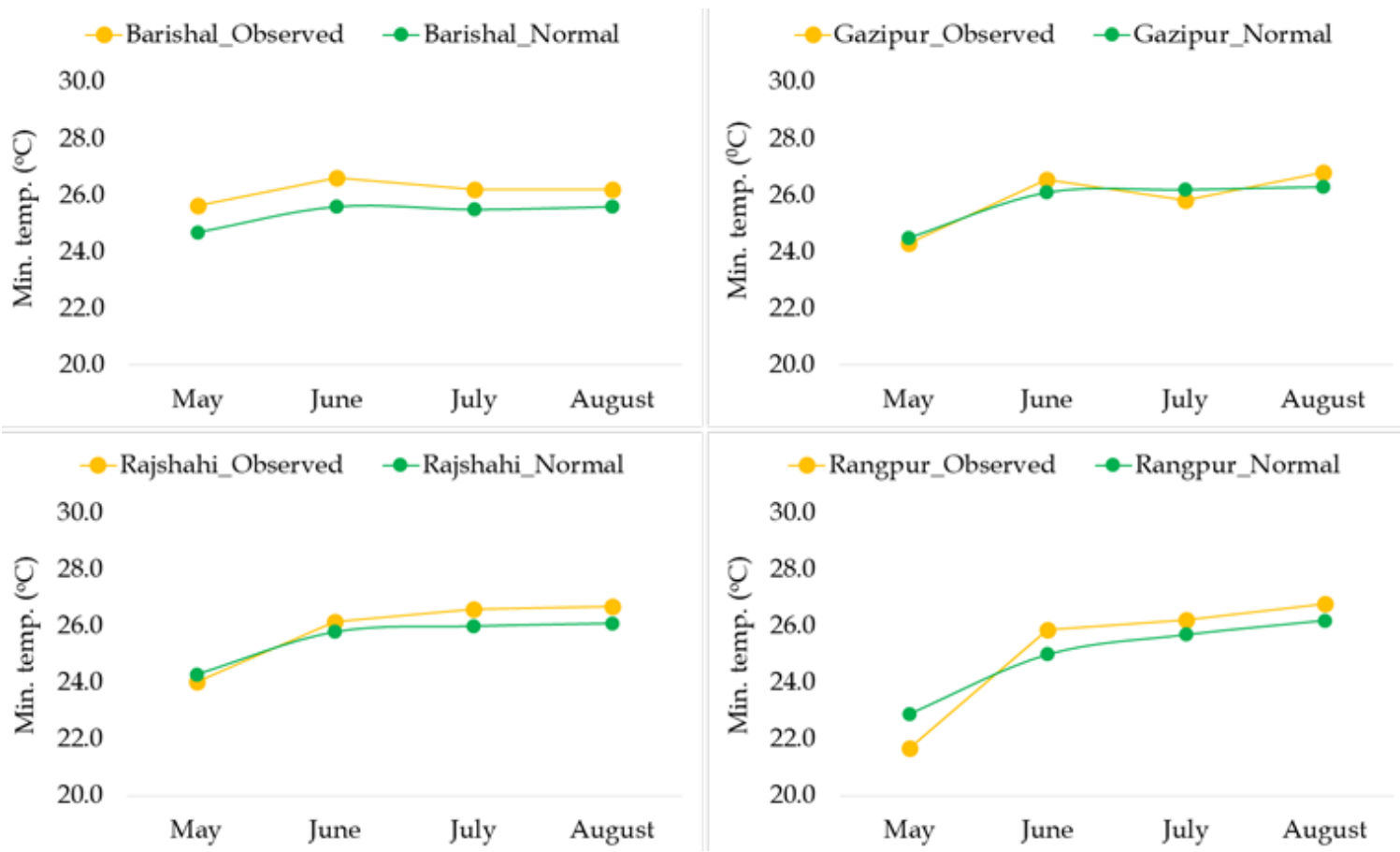

Fig. 3b. Monthly observed and normal average minimum temperature $\left({ }^{\circ} \mathrm{C}\right)$ for the experimental locations. 

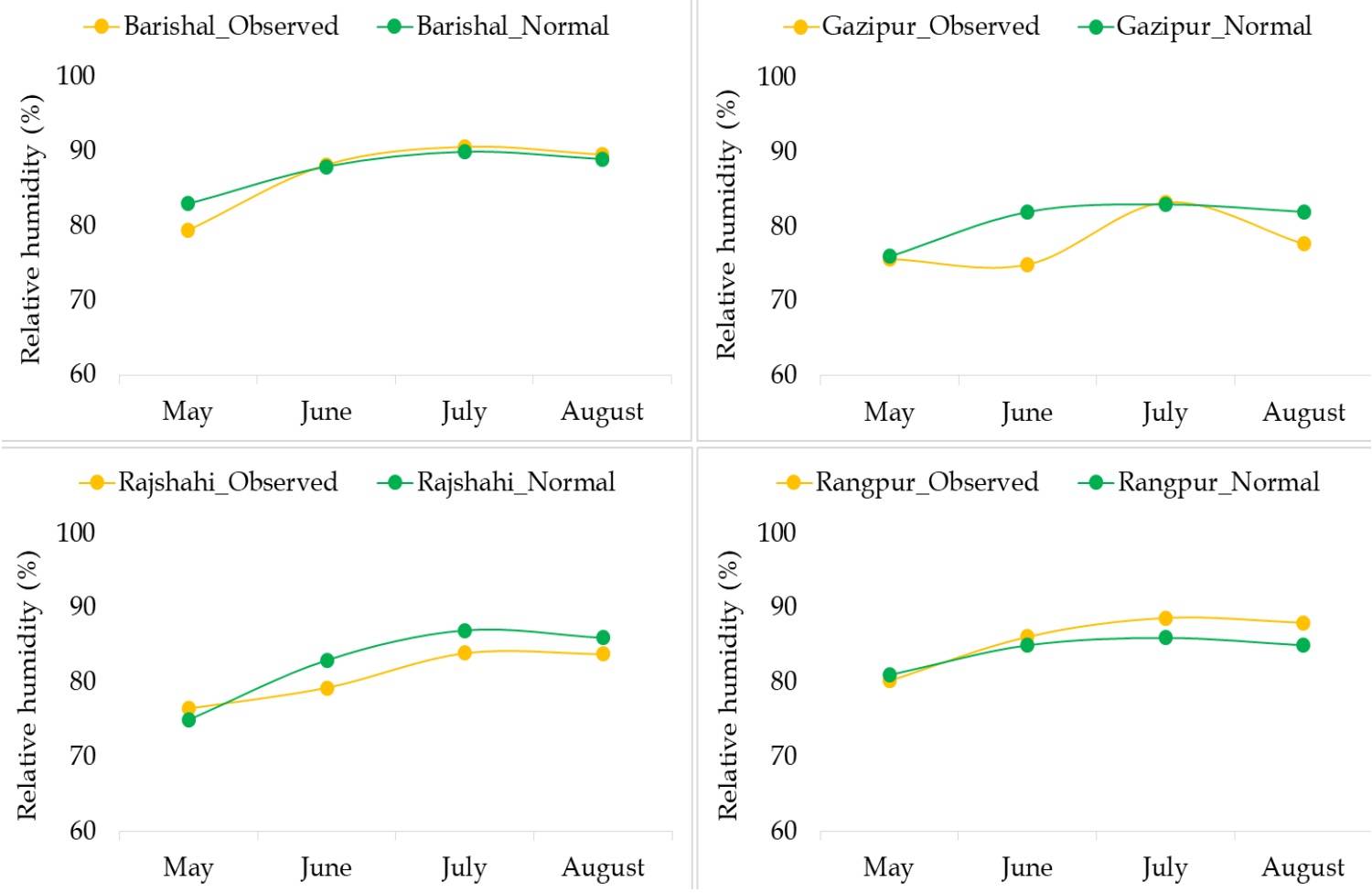

Fig. 3c. Monthly observed and normal average relative humidity (\%) for the experimental locations.

$\square$ Barishal_Observed $\square$ Barishal_Normal

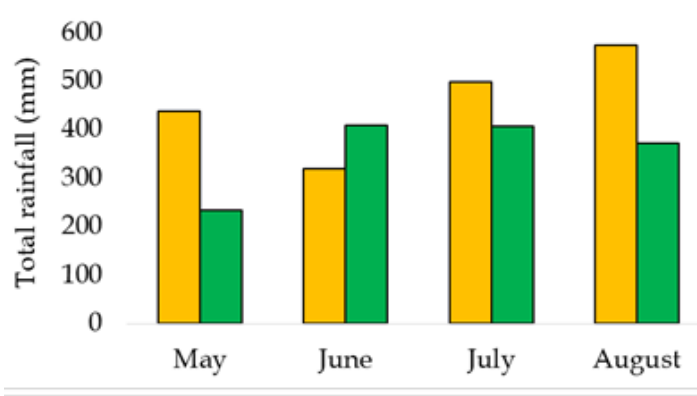

\section{$\square$ Rajshahi_Observed $\square$ Rajshahi_Normal}

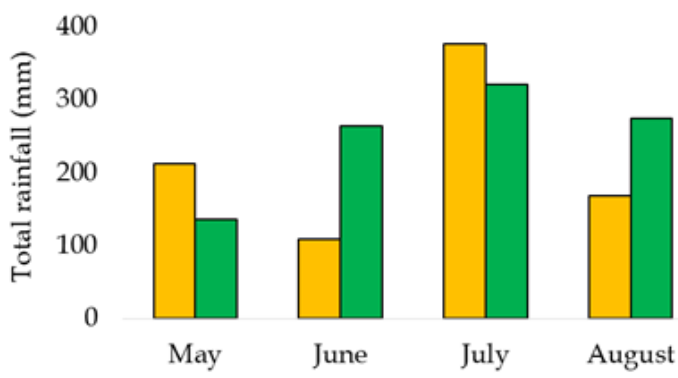

口Gazipur_Observed घGazipur_Normal

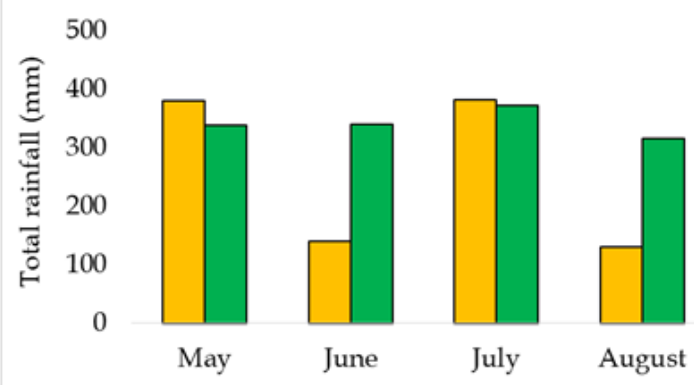

Fig. 3d. Monthly observed and normal total rainfall (mm) for the experimental locations.

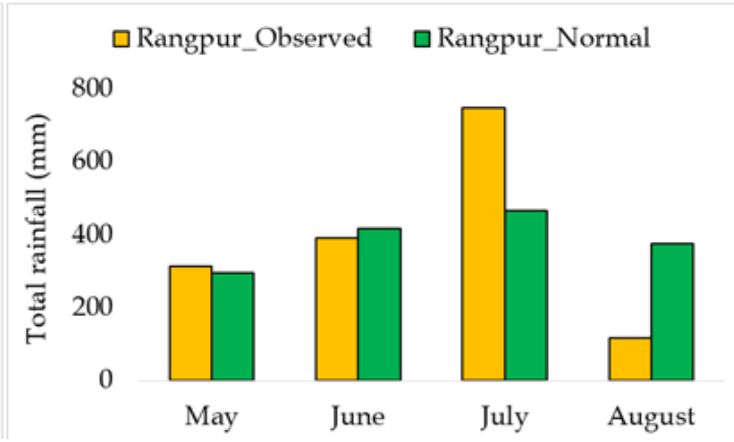




\section{Validation of WRF model predictions}

Quality management is a significant requirement for the use of meteorological information. For the acceptability of the use of model performance, validation of the predicted data is essential.Fig. 4 shows the general plot of WRF model predictions and observed data for max. temp., min. temp., relative humidity, and rainfall at Gazipur, Barishal, Rangpur, and Rajshahi.

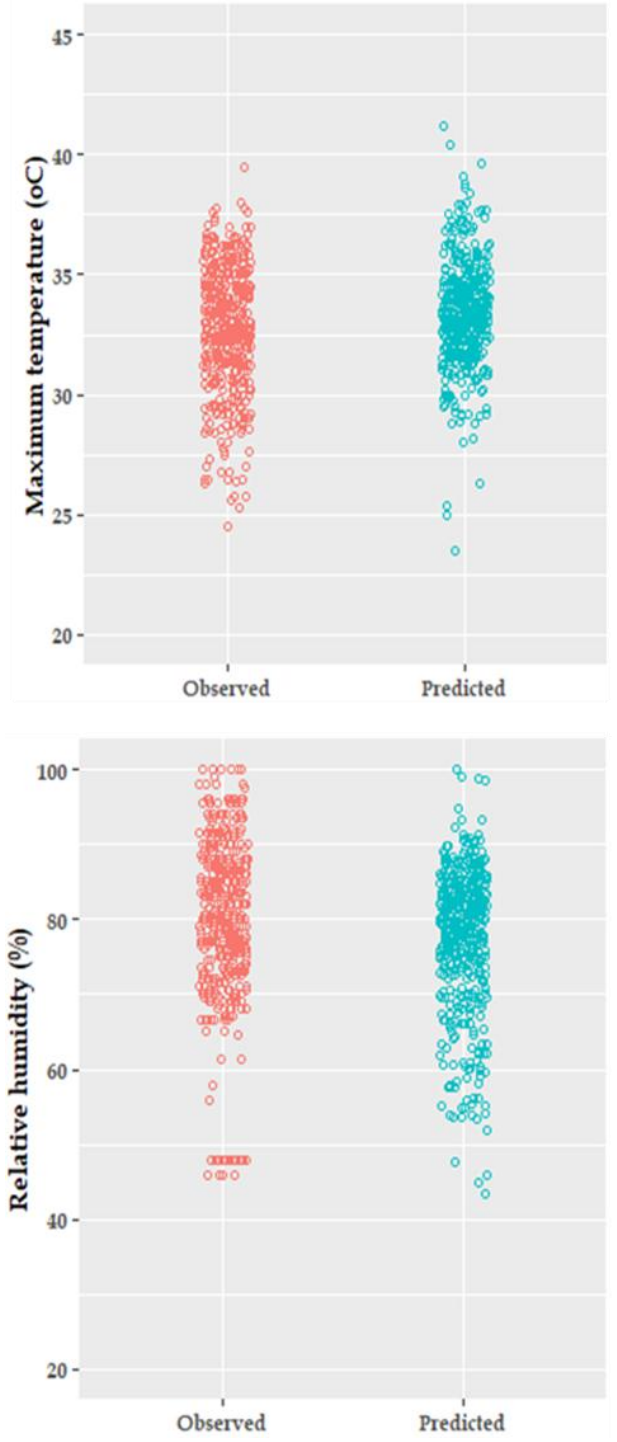

Irrespective of locations, the maximum temperature ranges from 23.5 to $41.2{ }^{\circ} \mathrm{C}$ in case of prediction and 24.5 to $39.5{ }^{\circ} \mathrm{C}$ for observed cases. Similarly, it was 23.1 to $30.8^{\circ} \mathrm{C}$ and 20.4 to $33.7{ }^{\circ} \mathrm{C}$ for predicted and observed cases, respectively in minimum temperature. The relative humidity ranges from 43.5 to $100 \%$ and 46 to $100 \%$, and rainfall ranges from 0 to $172.1 \mathrm{~mm}$ and 0 to $210.6 \mathrm{~mm}$, respectively for the predicted and observed data.
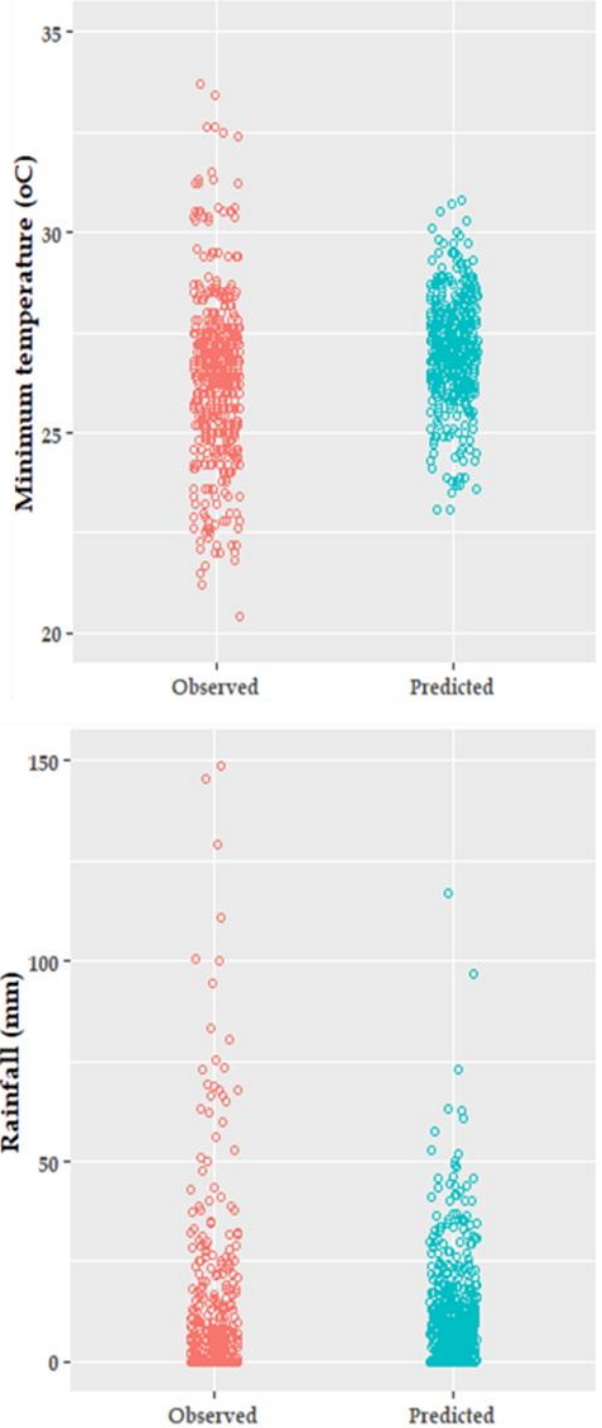

Fig. 4. Plot of WRF model predictions and observed data for four locations. 
The results of NRMSE and relBias for WRF model predictions are summarized in Figs. 5 and 6. NRMSE quantifies the size of the error with respect to the mean of the observed data.

Therefore, the results show that the highest NRMSE values were shown by Rangpur for maximum temperature, and Rajshahi for minimum temperature, relative humidity, and rainfall, suggesting that errors are typically around $8.2,11.1,20.2$, and $19.3 \%$ of the mean value for 24 hour lead time, respectively. Besides, the lowest NRMSE amongst maximum temperature, minimum temperature, relative humidity, and rainfall were exhibited by $4.6,8$, 9.4, and $6.7 \%$ at Gazipur, respectively. For 72 hour lead time, the highest NRMSE 7.4\%, and $9.4 \%$ at Rangpur for max. temp., and min. temp., and 18, and $19.3 \%$ in Rajshahi for relative humidity, and rainfall. And the lowest were 4.9, 5.7 , and $2.5 \%$ for maximum temperature, minimum temperature, and rainfall at Gazipur, respectively and $7.6 \%$ in relative humidity at Rangpur. In the case of 120 and 168 hours lead time, the highest values were 10.8 , and $12.2 \%$ in Rangpur for max. temp., 10.2, and $10.3 \%$ in

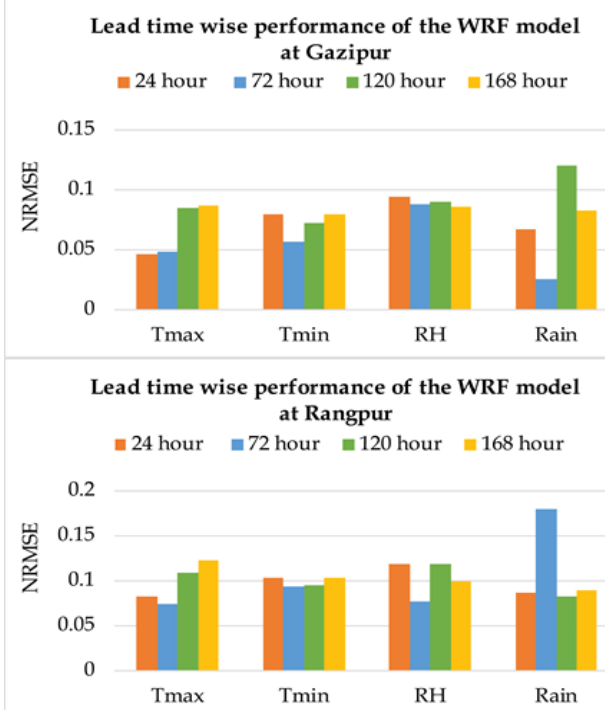

Rajshahi, and Rangpur for min. temp., 17.4, and $16.5 \%$ for relative humidity, and 21.7 , and $22 \%$ for rainfall in Rajshahi, respectively. Moreover, the lowest values were $6.8,7.2,6.2$, and $8.2 \%$ in maximum temperature, minimum temperature, relative humidity, and rainfall at Rajshahi, Gazipur, Barishal, and Rangpur, respectively. For maximum temperature, minimum temperature, relative humidity, and rainfall, were $5.2,7.9,8.5$, and $1 \%$ at Rajshahi, Gazipur, and Barishal, respectively. The low NRMSE for max. temp., min. temp., relative humidity, and rainfall were computed in most of the locations, which signifies the capability of this model to provide an accurate prediction. Among the parameters and locations, the error lies between 1 to $20.2 \%$ which means almost 79.2 to $99 \%$ accuracy has been achieved in comparison with the observed data. Therefore, the WRF model predicted the weather parameters with low NRMSE indicating fairly good agreement with observed data. Only the location Rajshahi exhibited high NRMSE residual results for relative humidity, and rainfall.

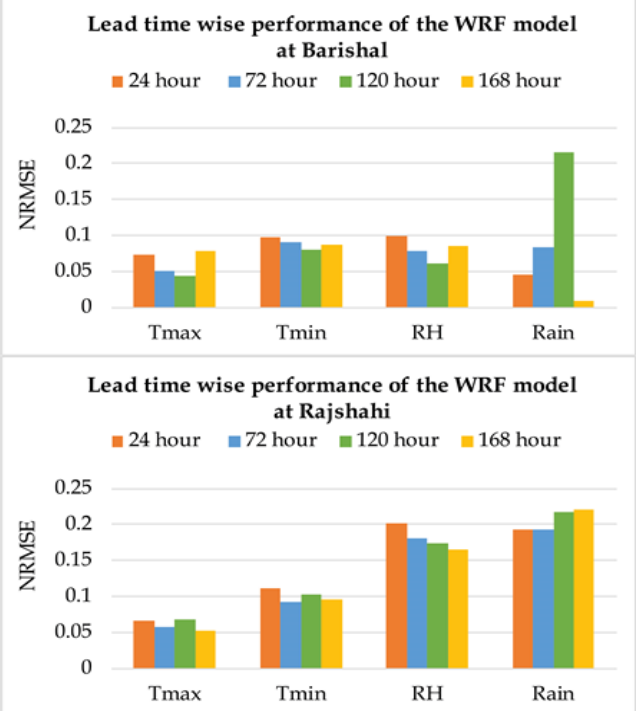

Fig. 5. Summarize the WRF model performance of max. temp., min. temp., relative humidity, and rainfall at different locations. NRMSE=Normalized root mean squared error. 


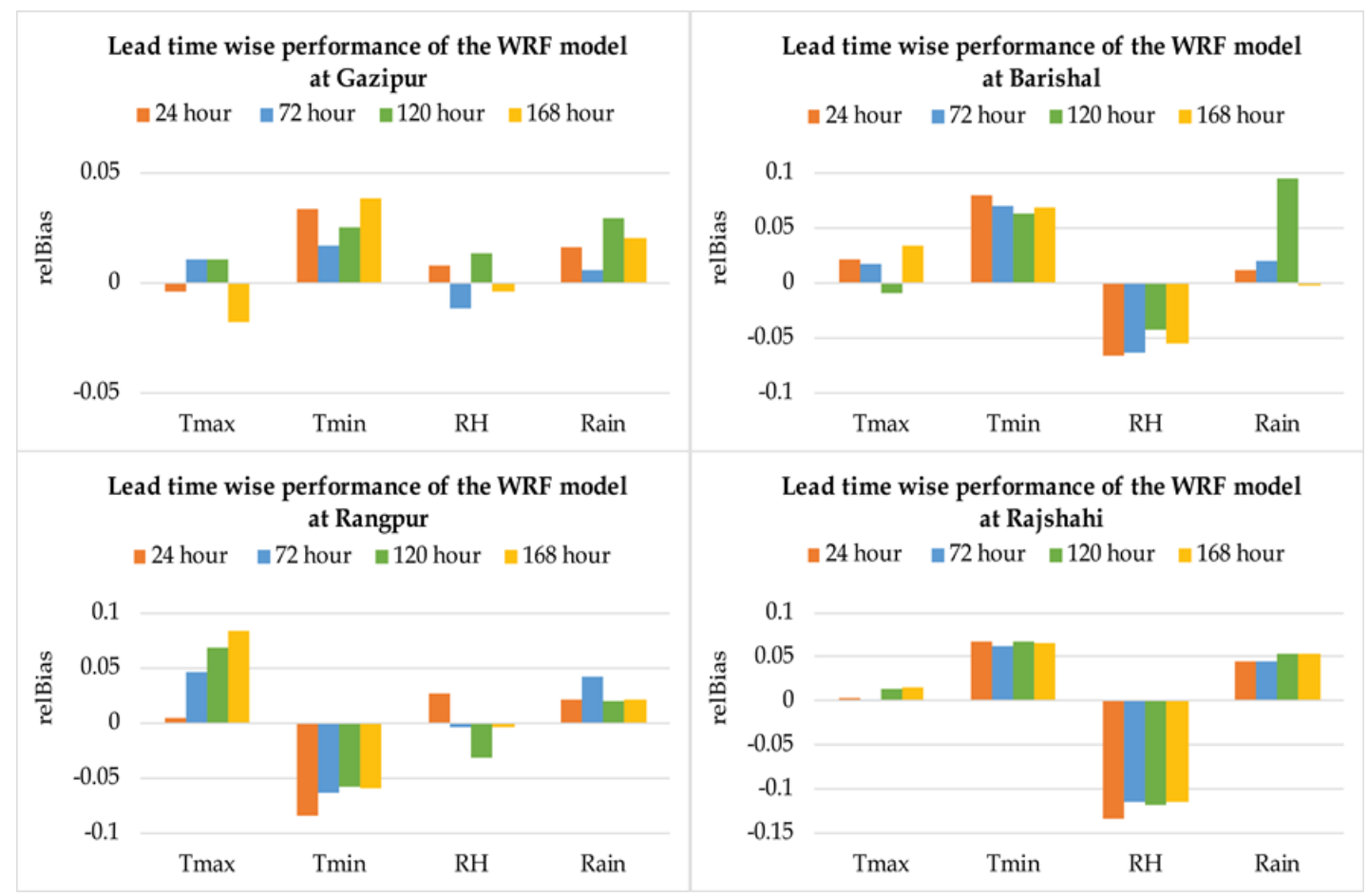

Fig. 6. Summarize the WRF model performance of max. temp., min. temp., relative humidity, and rainfall at different locations. relBias=Relative bias.

Furthermore, the relBias between the observed and predicted value using the WRF model for 24 hour lead time depicted that the max. temp. in Gazipur, min. temp. in Rangpur, and relative humidity in Barishal and Rajshahi showed underestimated (lower predictions than observed) results, which was $4 \%, 8.5 \%, 6.6 \%$, and $13.5 \%$, respectively.In the case of 72 hour lead time, the underestimations were $1.2 \%$ and $6.4 \%$ in Gazipur and Barishal for relative humidity, $6.3 \%$, and $0.4 \%$ for min. temp. and relative humidity in Rangpur, and $11.5 \%$ for relative humidity in Rajshahi, respectively. For 120 hour lead time, the model shows the underestimations of $1 \%$ and $4.3 \%$ for max. temp. and relative humidity in Barishal, 5.8 and $3.1 \%$ for min. temp. and relative humidity in Rangpur, and $11.9 \%$ for relative humidity in Rajshahi. 1.8 and $0.4 \%$ underestimation accounted for max. temp. and relative humidity in Gazipur for 168 hour lead time and it was 5.5 and $0.2 \%$ for relative humidity and rainfall in
Barishal, $6 \%$ and $0.5 \%$ for min. temp. and relative humidity in Rangpur, and $11.4 \%$ for relative humidity in Rajshahi, respectively. In the case of 24 hour lead time,the overestimation (higher predictions than observed) ranged from 0.3 to $2.1 \%$ for max. temp., 3.4 to $7.9 \%$ for $\min$. temp., 0.8 to $2.6 \%$ for relative humidity, and 1.1 to $4.5 \%$ for rainfall. The ranges were 0.2 to $4.7 \%$, 1.1 to $6.69 \%$, and 1.5 to $8.3 \%$ for max. temp., 1.7 to $7 \%, 2.5$ to $6.7 \%$, and 3.8 to $6.9 \%$ for $\mathrm{min}$. temp., and 0.6 to $4.5 \%, 2$ to $9.5 \%$, and 2 to $5.3 \%$ for rainfall in the case of 72, 120, and 168 hour lead time, respectively. Thus, relBias between the observed and predicted value showed very low overestimation and underestimation for the WRF model that signifies accurate predictions of the mentioned weather parameters. As the NRMSE and relBias values were comparatively less, the prediction model WRF is reliable. By comparing the predicted and observed values of max. temp., min. temp., relative humidity, and rainfall data using WRF model the 
predictions are sufficiently accurate. Therefore, the advisory generation based on the WRF model predictions of different parameters would be justified.

\section{Advisory dissemination system}

Based on the findings of the FGD, Figure 7 presents the advisory dissemination system.

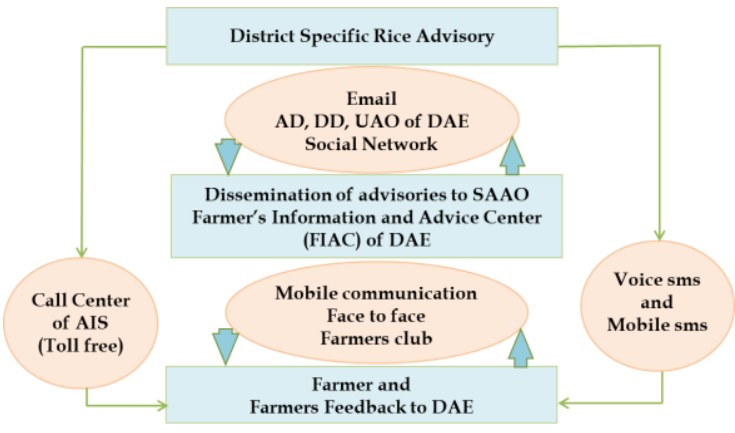

Fig. 7. Rice advisory service dissemination systems.

The generated location-specific advisories would be disseminated to the respective $A D$, DD, UAO, AEO, SAAO, and Farmers' Information and Advice Center (FIAC) of the DAE through email and directly to farmers by voice and text SMS. In addition, DD, UAO, SAAO's of FIAC would responsible for the dissemination of advisory bulletins to farmers in their respective areas through mobile communication, face-to-face meetings, or contact with the farmers club. The call center of Agricultural Information Service (AIS) can disseminate advisories to the farmers by voice SMS service and also inform the update if necessary. A toll-free number is essential to make the advisory service free for the farmers. Finally, farmers' feedback would also be incorporated regularly, if justifiable.

\section{Findings from numerous literature on weather forecast based advisory services}

There are some findings on the weather forecast-based advisory services and their impacts on crop management. In India, the National Center for Medium-Range Weather forecasting (NCMRWF) also evaluated the impact on various crops of weather-based agroadvisory services (Wheat, rice, millets, maize, red gram, chickpea, mustard, cumin, jute, cotton and tobacco, apricot, peach, banana, tomato, and spinach). Of the 127, 15 AAS units have been selected for impact study based on the existence of NCMRWF's effective weatherbased agro-advisory service. Two AAS contact farmers villages and 2 non-AAS contact farmers villages were selected on each unit. From each village, there were designated 20 AAS contact farmers and 20 non-AAS contact farmers. Finally, data were collected from 600 AAS and 600 non-AAS farmers. The study was carried out three years comprising of 3 Kharif and 3 Rabi seasons. In the case of rice, 7 stations (Raipur; Thrissur; Kalyani; Ludhiana; Bhubaneshwar; Hyderabad, and Pantnagar) were selected. The study revealed that the impact of AAS on the cost of cultivation decreased by $5-12 \%$ and gross return, net return, and yield increased by $8-20 \%, 16-20 \%$, and $8-20 \%$, respectively. Some researchers (Maini and Lathore, 2010; Chakraborty et al., 2018; Das et al., 2019) have been tested weatherbased management practice and termed as AAS over the traditional practice that is non-AAS in farmer's field and has found a net benefit of 6.7$15 \%$ in the overall yield of rice. Besides, they have also reported AAS to reduce 2-5\% cost of cultivation, gained $19.74 \%$ in net return, and earned more profit (USD 50.0 to USD 95.0) per ha of land over the non-AAS. A further study was carried out by the National Center for Agricultural Economics and Policy Research (NCAP) to assess the economic impact of weather forecast advisories during 1996, 2009, and 2015. The study reported that due to the adoption of agromet advisory services, farmers obtained an economic benefit of 10-25 percent (Chattopadhyay, 2018). Ananta Vashisth et al., (2013) and Khan et al., (2018) also studied the economic impact of agro-met advisory services on different crops and noticed that farmers can reduce input costs up to $6 \%$ in wheat, $9.6 \%$ in carrot, $2.4 \%$ in maize, $1.8 \%-7 \%$ in rice and 
increase net profit by $0.9 \%, 3 \%, 14 \%$ and $4-11 \%$, respectively.

\section{Performance of WFBAS in field experiment}

As already mentioned in the methodology, we used BRRI dhan48 in our experiment. The performance of BRRI dhan48 under WFBAS yielded better $\left(4.75\right.$ tha $\left.^{-1}\right)$ than control (3.91 tha${ }^{1}$ ). The research has demonstrated $21.48 \%$ (with a confidence interval of $4.33 \pm 1.96^{*} 0.123$ ) higher yield for field implications with forecast-based advisory service than the control plots (Fig. 8). The rice crop thus appears sensitive to weather changes, as the percentage of the yield variability was much greater.The reasons behind the yield advantage of the WFBAS over the control could be the proper utilization of chemical fertilizer and weather forecast-based insect management. In the WFBAS plot, the fertilizer application date was adjusted with the rainfall forecast. Whereas, the control plot was affected by rainfall after fertilizer application. The forecasted weather was favorable for stem borer (SB), therefore, the WFBAS took precautionary measures to prevent $\mathrm{SB}$ at the vegetative phase of the rice plant. On the other hand, the control plot used insecticides only after the emergence of SB.

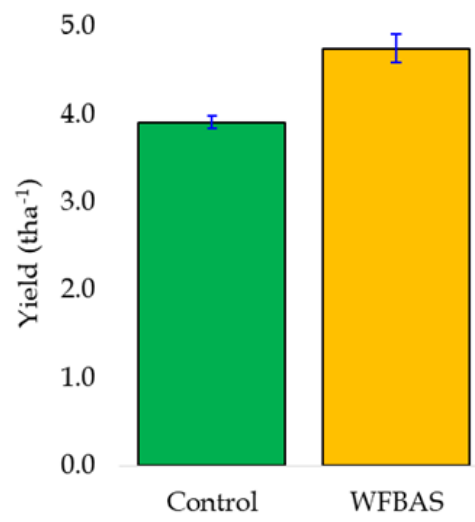

Fig. 8. Yield comparison between WFBASand traditional system.

Fig.9 showed the location-specific yield (tha-1) performance of BRRI dhan48 under two different management systems. Among all locations with WFBAS, the yield of Rajshahi was the highest (5.46 tha-1), followed by Gazipur (4.67 tha-1), Rangpur (4.55tha-1), and Barishal (4.32tha $\left.{ }^{-1}\right)$. In the same place,the yield of Rajshahi was the highest (4.17 tha-1) among the control plots, followed by Gazipur (4.03tha$\left.{ }^{1}\right)$, Rangpur (3.72tha- $\left.{ }^{-1}\right)$, and Barishal (3.72tha-1). BRRI dhan48 with the WFBAS showed significantly better yield performance than the control one irrespective of the location, but excellent has been observed in Rajshahi (30.94\%).

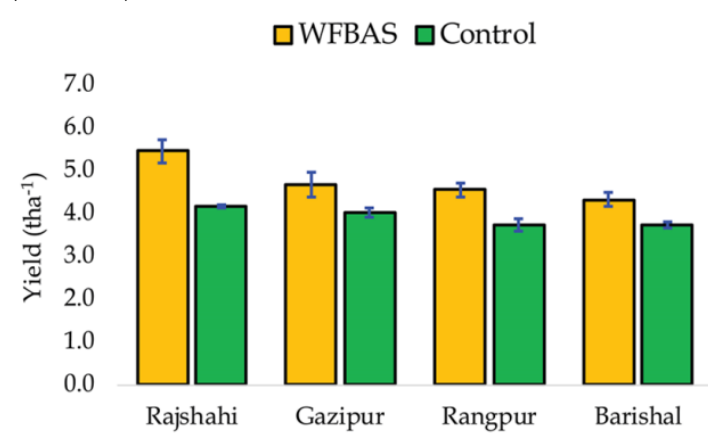

Fig. 9. Location-specific yield(tha-1) performance of BRRI dhan48dueto management systems. WFBAS=Weather forecast based advisory service.

\section{Impact assessment}

Our experimental findings reveal that the yield advantage of WFBAS is $21.48 \%$ over the control. However, the reviewed numerous literature found it $6.7-15 \%$. In order to show the minimum potentiality of this technology towards generating benefit in rice production, we considered only the minimum yield increment found in the literature. Therefore, this study used only $6.7 \%$ yield increment to show the impact of this technology on the total rough rice production in Bangladesh. Moreover, the results of the sensitivity analysis revealed that the adoption of this technology will stimulate total rough rice production by $0.034,0.069,0.103,0.138$, and 0.172 million tons, if only $1,2,3,4$, and $5 \%$ adoption rate can be ensured, respectively (Fig. 10). We have valued the farmers' additional benefit by adopting WFBAS technology in terms of actual 
(18.25 BDT per $\mathrm{kg}$ ) as well as the government declared rough rice farm-gate prices $(26.00$ BDT per kg) during 2018-19. The results showed that the nation will be benefited by adding 629, 1257, 1886, 2514, and 3143 million BDT, if only $1,2,3,4$, and $5 \%$ of farmers adopt the WFBAS, respectively. However, if the Government declared price can be ensured the benefit will be up to $896,1791,2687,3582$, and 4478 million BDT, respectively (Fig. 11).

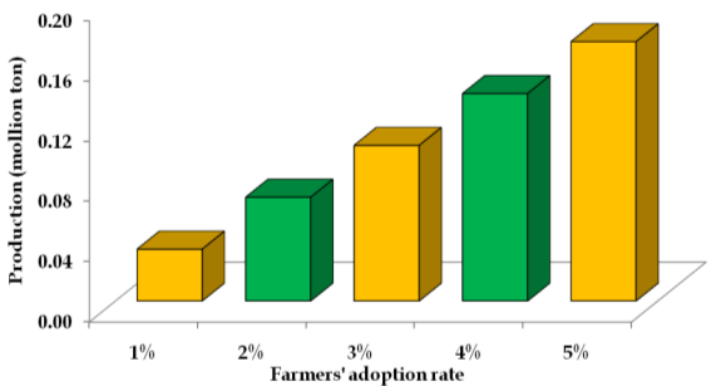

Fig. 10. Additional production through WFBAS. WFBAS=Weather forecast based advisory service.

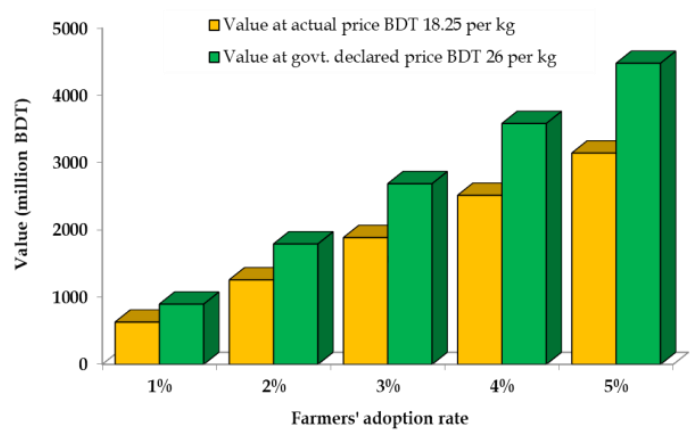

Fig. 11. Benefit from adopting WFBAS in rough rice production. WFBAS=Weather forecast based advisory service.

Therefore, increasing the adoption of this technology will certainly increase the national rice production and income of the farmers that will contribute significantly to ensure and sustain national food security. It is important to mention that the farmers' costs of production will remain the same or even can be reduced $(2-5 \%)$ if this technology is adopted successfully (Chakraborty et al., 2018). For implementing this technology, we recommend using the existing setup of BRRI and the DAE. Therefore, only voice and text SMS to farmers on rice advisories every 5 days interval will be required. The costs have been estimated as $12.05,24.09,36.14,48.18$, and 60.23 million BDT for $1,2,3,4$, and $5 \%$ farmers adoption, respectively. In this regard, the return on one BDT investment to this technology will be 51 BDT according to the actual price and 73 BDT if the government procured price is materialized at the farmgate level. The policies of the government should therefore go in favor of the widespread and effective dissemination of WFBAS to the end-users.

\section{Future prospects of WFBAS}

We already set a target of bringing $3 \%$ of total farmers under the WFBAS by 2025 , and $5 \%$ by 2030.The forecast results showed that the rough rice production would be increased by 0.119 million tons if the adoption goal of $3 \%$ is met by 2025 and that would be 0.214 million tons for $5 \%$ adoption by 2030 (Fig. 12).

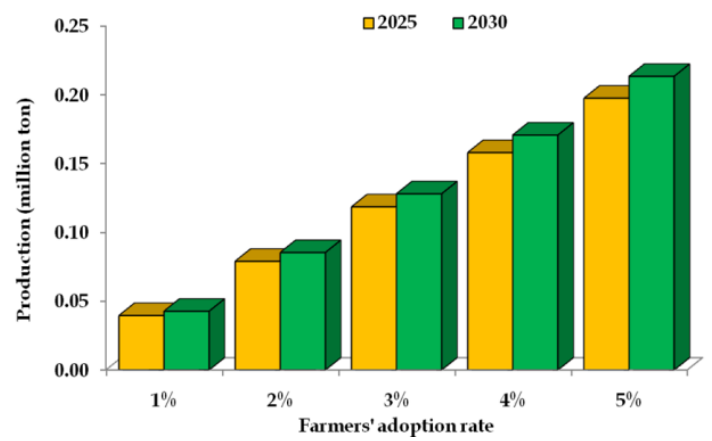

Fig. 12. Projected additional production through WFBAS. WFBAS=Weather forecast based advisory service.

Moreover, by the implementation of WFBAS, the return from the additional production would be BDT 2441 and BDT 5223 million at the rate of actually estimated rough rice prices 20.59 BDT per $\mathrm{kg}$ and 24.46 BDT per $\mathrm{kg}$ by 2025 and 2030, respectively. It will be 3522 and 6979 million BDT with the projected government procured price of 29.71 BDT per $\mathrm{kg}$ and 32.68 BDT per $\mathrm{kg}$, respectively (Fig. 13 and 14). 


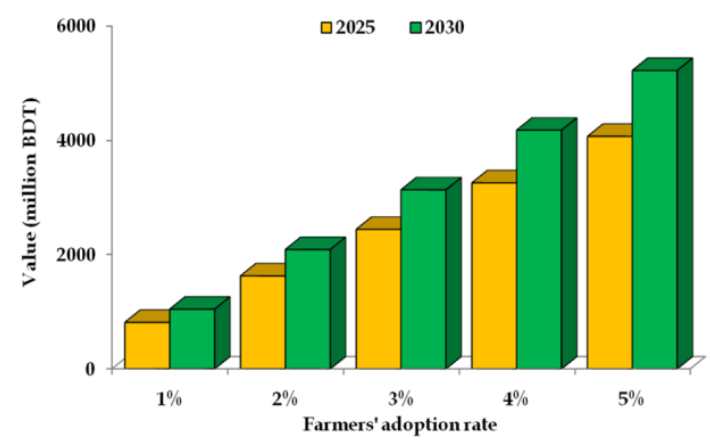

Fig. 13. Projected benefit from adopting WFBAS in rough rice production at the actual farmgate price. WFBAS=Weather forecast based advisory service.

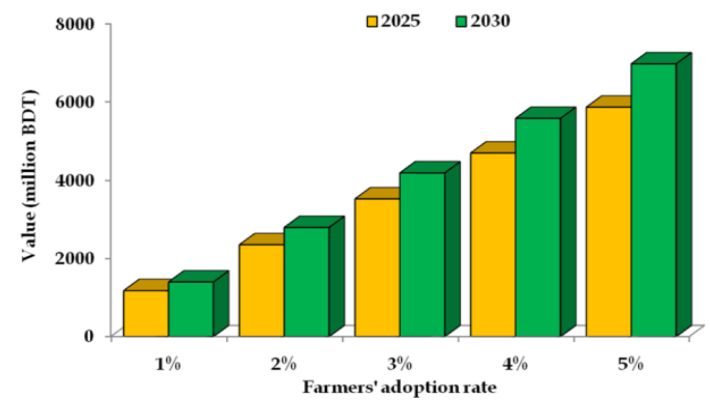

Fig. 14. Projected benefit from adopting WFBAS in rough rice production at the government procured price. WFBAS=Weather forecast based advisory service.

The estimated return according to the above projections will be 67 and 96 BDT from investing one BDT in this technology with the actual and government procurement prices by 2025, respectively, and that will be 86 BDT and 115 BDT by 2030 (Fig. 15). Therefore, the

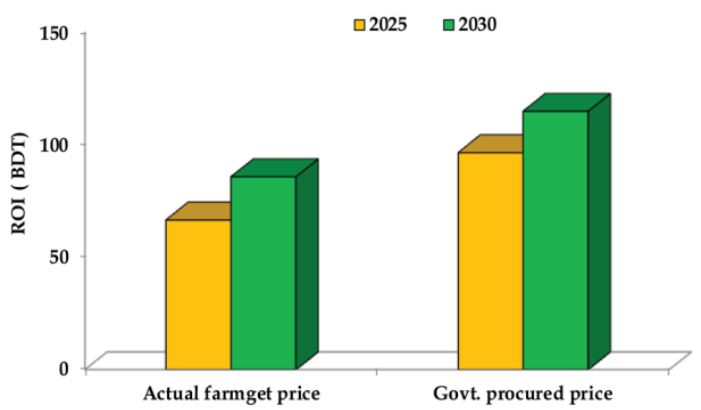

Fig. 15. Projected rate on investment from adopting WFBAS in rough rice production at the actual farmget and government procurement prices. ROI=Return on investment, WFBAS=Weather forecast based advisory service. investment in the dissemination of the WFBAS in the smart farming process will be much beneficial for sustainable rice production and increasing farmers' income.

\section{Research, development and extension (RDE) for three decades on enhancing rice production}

The RDE activities of developing weather forecast-based rice advisory services in Bangladesh have been drawn based on the three core pillars. These are- research \& development, dissemination, and feedback. These interlinkage pillars will work cyclically. Table 2 presents the decade-wise actionable programmes from the period 2021 to 2050 to establish the weather forecast-based rice advisory services. By 2030 we will develop the web-based decision support system (DSS) and identify the threshold level of the weather parameters responsible for insects and disease in different stages of rice crop. Our target is to bring $5 \%$ of rice farmers of the country under the advisory services in this decade and $50 \%$ in 2050. The developed database during 2021-2030 will be used to improve the DSS to make the advisory system automated during 2031-2040 and it will continue to upgrade based on the generated data from the experiment and field survey. The identification of threshold level of weather parameters responsible for insect and disease in different stages of rice crop will be continued. However, the feedback from the farmers, extension officials, and scientists/experts on the weather forecast-based rice advisory system and services will be incorporated in improving the DSS during 2041-2050 and beyond. Whereas, Table 3 presents the programme-specific activities (action plans) to materialize the ultimate goal of this study. 
Table 2. Decade wise actionable programmes.

Theme: Weather Forecast Based Rice Advisory Services

\begin{tabular}{|c|c|c|c|c|}
\hline \multirow{2}{*}{\multicolumn{2}{|c|}{ Pillar }} & \multicolumn{3}{|l|}{ Programmes } \\
\hline & & \multicolumn{3}{|l|}{ Period } \\
\hline \multirow{2}{*}{ Feedback } & $\begin{array}{l}\text { Research and } \\
\text { development }\end{array}$ & $\begin{array}{l}\text { 2021-2030 } \\
\text { - Development of web- } \\
\text { based decision } \\
\text { support system (DSS) } \\
\text { - Identification of the } \\
\text { threshold level of the } \\
\text { weather parameters } \\
\text { responsible for insect } \\
\text { and disease in } \\
\text { different stages of } \\
\text { rice crop }\end{array}$ & $\begin{array}{l}\text { 2031-2040 } \\
\text { - Improving the DSS } \\
\text { to make the } \\
\text { advisory system } \\
\text { automated } \\
\text { - Continuing the } \\
\text { identification of } \\
\text { threshold level of } \\
\text { weather parameters } \\
\text { responsible for } \\
\text { insect and disease } \\
\text { in different stages } \\
\text { of rice crop }\end{array}$ & $\begin{array}{l}\text { - Continuation of the } \\
\text { improvement of DSS } \\
\text { - Continuation of the } \\
\text { identification of } \\
\text { threshold level }\end{array}$ \\
\hline & Feedback & $\begin{array}{l}\text { - The adopted farmers } \\
\text { and extension } \\
\text { officials will provide } \\
\text { their opinions about } \\
\text { the service and } \\
\text { advisories }\end{array}$ & $\begin{array}{l}\text { - The adopted } \\
\text { farmers and } \\
\text { extension officials } \\
\text { will provide their } \\
\text { opinions about the } \\
\text { service and } \\
\text { advisories }\end{array}$ & $\begin{array}{l}\text { - The adopted farmers } \\
\text { and extension } \\
\text { officials will provide } \\
\text { their opinions about } \\
\text { the service and } \\
\text { advisories }\end{array}$ \\
\hline
\end{tabular}

\section{RECOMMENDATIONS}

- To enhance the productivity and profit from rice yield, a massive and efficient program for wider demonstration, refinement, and dissemination of weather forecast-based advisory service in an integrated way across the country should be taken.

- An automated decision support system should be established to transfer the advisory services from the origin to the end-users in the best and effective way.

- To make the system successful, we need to strengthen the capacity of BRRI, DAE, and develop the personnel accordingly through national and international expert linkage/training.

- A strong collaboration is required among the BRRI, Bangladesh Meteorological Department (BMD), Bangladesh Water
Development Board (BWDB), DAE, and end-users.

- As the farmers are the end-users of this technology, they should be well trained in Weather Forecast Based Advisory Service (WFBAS) system.

- The government should ensure quick and adequate supports regarding the popularization, adoption, and proper use of WFBAS.

- We place a target here to bring only $5 \%$ of total farmers under this technology by 2030, which will contribute significantly as one of the vital factors for achieving the SDG target 2.3: doubling the agricultural productivity under goal 2: zero hunger.

- The results of this study will provide suitable guidelines to the policymakers towards formulating policy decisions on implementing WFBAS. 
Table 3.The program-specific research, development, and extension activities.

\begin{tabular}{|c|c|c|c|c|c|c|c|}
\hline \multirow{2}{*}{ Program } & \multirow{2}{*}{ Action } & \multicolumn{2}{|c|}{ 2021-2030 } & \multicolumn{2}{|c|}{ 2031-2040 } & \multicolumn{2}{|c|}{ 2041-2050 } \\
\hline & & 2021-2025 & 2026-2030 & 2031-2035 & 2036-2040 & 2041-2045 & 2046-2050 \\
\hline \multirow{7}{*}{$\begin{array}{l}\text { Development of web-based } \\
\text { decision support system } \\
\text { (DSS) }\end{array}$} & $\begin{array}{l}\text { Development of user } \\
\text { interface of web-based } \\
\text { decision support system to } \\
\text { generate weather forecast } \\
\text { based advisories }\end{array}$ & & & & & & \\
\hline & $\begin{array}{l}\text { Establish collaboration } \\
\text { with the Bangladesh } \\
\text { Meteorological } \\
\text { Department }\end{array}$ & & & & & & \\
\hline & $\begin{array}{l}\text { Medium range weather } \\
\text { forecasting system } \\
\text { development using } \\
\text { Numerical Weather } \\
\text { Prediction (NWP) model }\end{array}$ & & & & & & \\
\hline & - Model validation & & & & & & \\
\hline & $\begin{array}{l}\text { Integrating the forecast } \\
\text { model to the DSS }\end{array}$ & & & & & & \\
\hline & $\begin{array}{l}\text { Developing the advisory } \\
\text { generating system to the } \\
\text { DSS }\end{array}$ & & & & & & \\
\hline & $\begin{array}{l}\text { Respective experts will } \\
\text { provide action oriented } \\
\text { advisories under the DSS }\end{array}$ & & & & & & \\
\hline \multirow{6}{*}{$\begin{array}{l}\text { Identification of the } \\
\text { threshold level of the } \\
\text { weather parameters } \\
\text { responsible for insect and } \\
\text { disease in different stages of } \\
\text { rice crop }\end{array}$} & $\begin{array}{l}\text { Establish collaboration } \\
\text { with the entomology and } \\
\text { plant pathology division } \\
\text { of BRRI }\end{array}$ & & & & & & \\
\hline & $\begin{array}{l}\text { Laboratory facility } \\
\text { development and } \\
\text { manpower engagement }\end{array}$ & & & & & & \\
\hline & $\begin{array}{l}\text { - Experimentation and field } \\
\text { survey }\end{array}$ & & & & & & \\
\hline & - Data collection & & & & & & \\
\hline & $\begin{array}{l}\text { Data analysis and } \\
\text { reporting }\end{array}$ & & & & & & \\
\hline & $\begin{array}{l}\text { Validation of the } \\
\text { experimental findings }\end{array}$ & & & & & & \\
\hline \multirow{5}{*}{$\begin{array}{l}\text { At least } 5 \% \text { rice farmers will } \\
\text { be brought under the } \\
\text { advisory services }\end{array}$} & $\begin{array}{l}\text { - Establishment of } \\
\text { collaboration with DAE }\end{array}$ & & & & & & \\
\hline & $\begin{array}{l}\text { - Improving research- } \\
\text { extension-farmer network }\end{array}$ & & & & & & \\
\hline & $\begin{array}{l}\text { Development of } \\
\text { automated advisory } \\
\text { dissemination system } \\
\text { under DSS }\end{array}$ & & & & & & \\
\hline & $\begin{array}{l}\text { - Providing training to the } \\
\text { extension officials and } \\
\text { farmers }\end{array}$ & & & & & & \\
\hline & $\begin{array}{l}\text { - Conducting } \\
\text { demonstration }\end{array}$ & & & & & & \\
\hline $\begin{array}{l}\text { The adopted farmers and } \\
\text { extension officials will } \\
\text { provide their opinions } \\
\text { about the service and } \\
\text { advisories }\end{array}$ & $\begin{array}{l}\text { Development of } \\
\text { automated feed backing } \\
\text { and responding system } \\
\text { for farmers, extension } \\
\text { officials and researcher in } \\
\text { the DSS }\end{array}$ & & & & & & \\
\hline \multirow[t]{2}{*}{$\begin{array}{l}\text { Improving the DSS to make } \\
\text { the advisory system } \\
\text { automated }\end{array}$} & $\begin{array}{l}\text { Development of data base } \\
\text { from the advisories, } \\
\text { experiment, field survey } \\
\text { and feedback during } 2021 \text { - } \\
2030\end{array}$ & & & & & & \\
\hline & $\begin{array}{l}\text { - Incorporating the } \\
\text { gathered data in the DSS }\end{array}$ & & & & & & \\
\hline \multirow{2}{*}{$\begin{array}{l}\text { More } 20 \% \text { rice farmers will } \\
\text { be brought under the } \\
\text { advisory services }\end{array}$} & $\begin{array}{l}\text { - Providing training to the } \\
\text { extension officials and } \\
\text { farmers }\end{array}$ & & & & & & \\
\hline & $\begin{array}{l}\text { - Conducting } \\
\text { demonstration }\end{array}$ & & & & & & \\
\hline \multirow{2}{*}{$\begin{array}{l}\text { Continuation of the } \\
\text { improvement of DSS }\end{array}$} & $\begin{array}{l}\text { Incorporating } \\
\text { continuously gathered } \\
\text { data in the DSS }\end{array}$ & & & & & & \\
\hline & $\begin{array}{l}\text { - Continuous up gradation } \\
\text { and feedback based } \\
\text { adjustment of DSS }\end{array}$ & & & & & & \\
\hline \multirow{2}{*}{$\begin{array}{l}\text { Additional } 25 \% \text { rice farmers } \\
\text { will be brought under the } \\
\text { advisory services }\end{array}$} & $\begin{array}{l}\text { Providing training to the } \\
\text { extension officials and } \\
\text { farmers }\end{array}$ & & & & & & \\
\hline & $\begin{array}{l}\text { - Conducting } \\
\text { demonstration }\end{array}$ & & & & & & \\
\hline
\end{tabular}




\section{LIMITATIONS OF THE STUDY}

- Preliminarily, our data did not allow us to identify the exact causes of yield advantages critically. While efforts should be made to identify the exact causes of yield enhancement under WFBAS.

- This study only reflects on a single-season multiple location experiment. It is important to conduct the same experiment in multiple seasons in the farmers' field.

\section{CONCLUSION}

The implementation of a weather-based advisory service (WFBAS) has the potentiality to boost rough rice production byenhancing productivity in Bangladesh. The findings of this study show that the adoption of weatherbased management practices can increase grain yield by $6.7-21.48 \%$ and reduces the cost of productionabout $12 \%$.If only $5 \%$ of rice farmers would adopt the WFBAS, the minimum probability of yield increase $(6.70 \%)$ will add 0.172 million tons of rough rice to the national food basket, the value of which will add about 4478 million BDT to the national GDP. If WFBAS is materialized properly at the entire production system (such as research, extension, and farm), one BDT investment will return 51-73 BDT for the nation. The WFBAS is found very much effective for the farmers as it provides not only the weather forecast information but also technical guidance on the cultivation aspects including timely transplanting and application of fertilizer/ water/pesticides/herbicides/ insecticides. It also saves inputs such as water, manpower, electricity, and fuel, through proper irrigation scheduling. The study has targeted to adopt the WFBAS by 5\% farmers at 2030 and projected the outcomes as additional 0.214 million tons national rough rice production that will add BDT 5223 million as the contribution of rice sector to the national GDP. Therefore, the adoption of WFBAS will increase the national agricultural income significantly through increasing rice productivity. Moreover, the projected returns from adopting WFBAS in rice farming will guide the policymakers to take necessary decisions and actions for the establishment, upgrading, and dissemination of this technology to the stakeholders.

\section{ACKNOWLEDGEMENTS}

The authors are very much grateful to the Agrometeorology and Crop Modeling Laboratory of BRRI for all kinds of support and at the same time, thankfully, we extend our gratitude to all the members of the Agromet lab.We also want to acknowledge the Plant Physiology Division of BRRI for providing the observed data, Bangladesh Meteorological Department (BMD) for the supervision of the generation of locationspecific weather forecast by Agromet lab for this research, Mr Raihanul Haque Khan and Mr Nazmul Ahasan from RIMES, Bangladesh for their valuable suggestions and create scope for attending into the FGD's and collecting data regarding early warning and advisory dissemination system.

\section{AUTHORS' CONTRIBUTION}

NMFR and MSK conceptualized the study; MSK, MUS, NMFR, MARS and MAAM coordinated the study; NMFR developed methodology, assembled all the data sets, performed the statistical analysis, prepared the figures, and wrote the first draft of the manuscript; MCR provided scientific insightsand performed economic analysis; $\mathrm{MMH}, \mathrm{ABMZH}, \mathrm{MMH}, \mathrm{TH}, \mathrm{MKAB}$, and MAIK provided advisories for field experiment; NMFR, MIH, MAA, MAAM, $M A Q, R A$, and $A C$ contributed to managing the location-specific weather forecasts in collaboration with Bangladesh Meteorological Department; MAB, SMQH, MIH, MARS, MUS, and MSK performed critical review and editing; All authors read and approved the final manuscript. 
DECLARATION OF INTERESTS

A version of the paper was published in a book "Doubling Rice Productivity in Bangladesh" in 2020 by the Bangladesh Rice Research Institute (BRRI), Gazipur 1701, Bangladesh to commemorate BRRI's $50^{\text {th }}$ anniversary. The Bangladesh Rice Journal has prior knowledge of the book publication and does not see any conflict of interest.

\section{REFERENCES}

Belle, A. 2019. Bangladeshi farmers reap the benefit of new weather forecasts. A report of the end poverty in south Asia, World Bank. https://blogs.worldbank.org/endpovertyinsouth Asia/Bangladeshi-farmers-reap-benefits-newweather-forecasts.

BMD (Bangladesh Meteorological Department). 2020. http:/ /live.bmd.gov.bd/

Brolley, M. 2015. Rice security is food security for much of the world. Rice Today. International Rice Research Institute (IRRI), DAPO Box 7777, Metro Manila, Philippines. pp. 30-32.

BRRI (Bangladesh Rice Research Institute). 2017.Annual Report 2016-17. Bangladesh Rice Research Institute, Gazipur-1701, Bangladesh.

BRRI (Bangladesh Rice Research Institute). 2018.Annual Report 2017-18. Bangladesh Rice Research Institute, Gazipur-1701, Bangladesh.

Chai, T and R R Draxler. 2014. Root mean square error (RMSE) or mean absolute error (MAE)? - arguments against avoiding RMSE in the literature. Geoscientific Model Development, 7 (3): 1247-1250.

Chakraborty, A J, S Banerjee, A Mukherjee, M D Bairagya and S Ghosh. 2018. Climate Change and Weatherbased Agrometeorological Advisory Service: an Analysis from Farmers' Perspectives. Italian Journal of Agrometeorology, 23 (3): 5-14.

Chattopadhyay, N and S Chandras. 2018. Agrometeorological advisory services for sustainable development in Indian agriculture. Biodiversity Int J., 2 (1): 13 $\square 18$. DOI: 10.15406/bij.2018.02.00036.

DAE (Department of Agricultural Extension). 2020. Weekly crop production report. Departmentof Agricultural Extension, Ministry of Agriculture, Government people's republicof Bangladesh, Dhaka, Bangladesh.

Das, H. 2019. Assessment of Economic Profitability of Weather Based Agro Advisory Services on Rice.
International Journal of Agriculture Sciences, 11 (6): 8121-8123.

Das, H P, F J Doblas-Reyes, A Garcia, J Hansen, L Mariani, A Nain, K Ramesh, L S Rathore, R Venkataraman and A Garcia. 2010. Weather and climate forecasts for agriculture. Guide to Agricultural Meteorological Practices, pp. 5-1.

FAO (Food and Agricultural Organization). 2017a. the future of food and agriculture-Trends and challenges. Annual Report. http://www.fao.org/3/a-i6583e.pdf

FAO (Food and Agricultural Organization). 2017b. GIEWS Update, Bangladesh Severe floods in 2017 affected large numbers of people and caused damage to the agriculture sector.

Frisvold, G B and A Murugesan. 2013. Use of weather information for agricultural decision making. Weather, Climate, and Society, 5 (1): 55-69.

HIES (Household Income and Expenditure Survey). 2016. Household Income and Expenditure Survey 2016. Bangladesh Bureau of Statistics. Ministry of Planning, Government of the People's Republic of Bangladesh, Sher-e-Bangla Nagar, Bangladesh.

Hollinger, S E and J R Angel. 2009. Weather and crops. Illinois agronomy handbook, pp. 1-12.

Kabir, M S, M U Salam, A Chowdhury, N M F Rahman, K M Iftekharuddaula, M S Rahman, M H Rashid, S S Dipti, A Islam, M A Latif, A K M S Islam, M M Hossain, B Nessa, T H Ansari, M A Ali and J K Biswas. 2015. Rice Vision for Bangladesh: 2050 and Beyond. Bangladesh Rice Journal, 19 (2): 1-18. DOI: 10.3329/brj.v19i2.28160.

Kabir, M S, M U Salam, A K M S Islam, M A R Sarkar, M A A Mamun, M C Rahman, B Nessa, M J Kabir, H B Shozib, M B Hossain, A Chowdhury, M Nasim, K M Iftekharuddaula, M S Hossain, M K A Bhuiyan, B Karmakar, M S Rahman, M M Haque, M T Khatun, M P Ali, S M H A Rabbi, P L Biswas, E S M H Rashid and N M F Rahman. 2020. Doubling rice productivity in Bangladesh: A way to achieving SDG2 and moving forward. Bangladesh Rice Journal, 24 (2): 1-47.

Khan, N, A Kumar, C B Singh, V Dubey and N Kumar. 2018. Weather Based Agro-Met Advisory to Enhance the Production and Income of the Farmers under Changing Climate Scenario of Central Plain Zone of Uttar Pradesh, India. Int.J.Curr.Microbiol.App.Sci.,7 (11): 221224.

Maini, P and L S Rathore. 2011. Economic impact assessment of the Agrometeorological Advisory Service of India. Current Science, 101 (10): 1296-1310. 
Mechiche-Alami, A and A M Abdi. 2020. Agricultural productivity in relation to climate and cropland management in West Africa. Scientific reports, 10 (1): $1-10$.

MoF (Ministry of Food). 2019. Government domestic Boro procurement in Bangladesh. Ministry of Food, Government of the People's Republic of Bangladesh, Dhaka, Bangladesh.

Nelson, A R L E, K Ravichandran and U Antony. 2019. The impact of the Green Revolution on indigenous crops of India. Journal of Ethnic Foods, 6(1):8.

Nesheim, I, L Barkved and N Bharti. 2017. What is the role of agro-met information services in farmer decisionmaking? Uptake and decision-making context among farmers within three case study villages in Maharashtra, India. Agriculture, 7 (8): 70.

Powers, J G, J B Klemp, W C Skamarock, C A Davis, J Dudhia, D O Gill, J L Coen, D J Gochis, R Ahmadov, S E Peckham and G A Grell. 2017. The weather research and forecasting model: Overview, system efforts, and future directions. Bulletin of the American Meteorological Society, 98 (8): 1717-1737.

Rahman, M C, V Pede, J Balie, I M Pabuayon, J M Yorobe and S Mohanty. 2020. Assessing the market power of millers and wholesalers in the Bangladesh rice sector. Journal of Agribusiness in Developing and Emerging Economies. DOI: 10.1108/JADEE-04-2018-0053.

Rathore, L S and N Chattopadhyay. 2016. Weather and climate services for farmers in India. Int. J. Agriculture and Food Security, 65 (2).

Siddique, M A B, M A Salam and M C Rahman. 2020. Estimating the Demand Elasticity of Rice in Bangladesh: An Application of the AIDS Model. Asian Journal of Agriculture and Rural Development, 10 (3): 721-728.

SYB (Statistical Yearbook of Bangladesh). 2018. Statistical Yearbook of Bangladesh 2018. Bangladesh Bureau of Statistics, Statistics and Informatics Division, Ministry of Planning, Government of the People's Republic of Bangladesh, Dhaka, Bangladesh.

Vashisth, A, R Singh, D K Das and R Baloda. 2013. Weather Based Agromet Advisories for Enhancing the Production and Income of the Farmers under Changing Climate Scenario. International Journal of Agriculture and Food Science Technology, 4 (9): 847-850.

WB (World Bank). 2011. Climate Risk and Adaptation Country Profile: Vulnerability, Risk Reduction, and Adaptation to Climate Change, Senegal. World Bank. 